Article

\title{
Development of Provesicular Nanodelivery System of Curcumin as a Safe and Effective Antiviral Agent: Statistical Optimization, In Vitro Characterization, and Antiviral Effectiveness
}

\author{
Farid A. Badria ${ }^{1}$, Abdelaziz E. Abdelaziz ${ }^{2}$, Amira H. Hassan ${ }^{3}$, Abdullah A. Elgazar ${ }^{4}$ (D) \\ and Eman A. Mazyed ${ }^{2, *}$ \\ 1 Department of Pharmacognosy, Faculty of Pharmacy, Mansoura University, Mansoura 35516, Egypt; \\ badri002@mans.edu.eg \\ 2 Department of Pharmaceutical Technology, Faculty of Pharmacy, Kafrelsheikh University, \\ Kafrelsheikh 33516, Egypt; Abdelaziz_abdrabo@pharm.kfs.edu.eg \\ 3 Department of Pharmaceutics, Faculty of Pharmacy, Beni-Suef University, Beni-Suef 62511, Egypt; \\ amira.abdelatef@pharm.bsu.edu.eg \\ 4 Department of Pharmacognosy, Faculty of Pharmacy, Kafrelsheikh University, Kafrelsheikh 33516, Egypt; \\ Abdulah.elgazar@phr.mans.edu.eg \\ * Correspondence: eman_mazyad@pharm.kfs.edu.eg; Tel.: +20-100-3484508
}

Academic Editors: Justin Jang Hann Chu and Chee Keng Mok

Received: 30 October 2020; Accepted: 28 November 2020; Published: 1 December 2020

check for updates

\begin{abstract}
Curcumin is a natural compound that has many medical applications. However, its low solubility and poor stability could impede its clinical applications. The present study aimed to formulate dry proniosomes to overcome these pitfalls and improve the therapeutic efficacy of Curcumin. Curcumin-loaded proniosomes were fabricated by the slurry method according to $3^{2}$ factorial design using Design-Expert software to demonstrate the impact of different independent variables on entrapment efficiency $(\mathrm{EE} \%)$ and \% drug released after $12 \mathrm{~h}\left(\mathrm{Q}_{12 \mathrm{~h}}\right)$. The optimized formula (F5) was selected according to the desirability criteria. F5 exhibited good flowability and appeared, after reconstitution, as spherical nanovesicles with EE\% of $89.94 \pm 2.31 \%$ and $\mathrm{Q}_{12 \mathrm{~h}}$ of $70.89 \pm 1.62 \%$. F5 demonstrated higher stability and a significant enhancement of $\mathrm{Q}_{12 \mathrm{~h}}$ than the corresponding niosomes. The docking study investigated the ability of Curcumin to bind effectively with the active site of DNA polymerase of Herpes simplex virus (HSV). The antiviral activity and the safety of F5 were significantly higher than Curcumin. F5 improved the safety of Acyclovir (ACV) and reduced its effective dose that produced a 100\% reduction of viral plaques. Proniosomes could be promising stable carriers of Curcumin to be used as a safe and efficient antiviral agent.
\end{abstract}

Keywords: Curcumin; proniosomes; optimization; molecular docking; antiviral activity

\section{Introduction}

Herpes simplex virus (HSV) is a highly contagious and endemic pathogen that causes herpes labialis, herpes genitalis, encephalitis, and keratitis [1]. HS viral infections are considered to be a significant health problem worldwide [2]. The HSV infection caused by both type 1 (HS-1) and type 2 (HS-2) viruses could be transmitted through close personal contact [3]. The clinical use of antiviral agents such as ACV, foscarnet, and ganciclovir results in severe adverse effects and the development of drug-resistant viruses that impede their long-term administration [4]. Hence, there is an urgent need for developing less toxic, cheap, and readily available, alternate antiviral agents for the treatment 
of HSV infection. Medicinal plants offer an effective alternative because of their safety, availability, and promising therapeutic effect [5].

Turmeric (Curcuma longa Linn) is generally recognized as safe (GRAS) by the FDA [6] and is extensively used as a folk medicine for its antioxidant, anti-inflammatory, and antiseptic effects, particularly in Asian countries [7]. Curcumin (1,7-bis(4-hydroxy-3-methoxyphenyl)-1,6-heptadiene-3,5-dione) is the main curcuminoid derived from turmeric rhizomes $[2,8]$. The therapeutic efficacy and safety of curcumin (up to $12 \mathrm{~g} /$ day) make it an attractive target for the prevention and treatment of different human diseases [9]. Curcumin has exhibited multiple clinical applications including anti-oxidant, anti-cancer, anti-inflammatory, anti-rheumatic, anti-microbial, and hepatoprotective effects [10]. Curcumin has also been investigated for its antiviral activity against a broad spectrum of viruses such as HSV, hepatitis virus, Zikavirus, Influenza virus, Adenovirus and coronavirus (COVID19) [11-14]. The antiviral activity of Curcumin against HSV could be attributed to interference with the metabolism of the virus through cell signaling and apoptosis $[12,13,15]$. However, the therapeutic applications of Curcumin have been hindered by its low aqueous solubility, low permeability, poor stability, and rapid in vivo degradation [16].

Nanotechnology is a rational approach that could overcome these pitfalls due to its ability to enhance the therapeutic efficacy of drugs and minimize their adverse effects by prolonging drug release through encapsulating drug within the vesicular carriers that can cross cell membranes [17]. Additionally, nanotechnology can improve the delivery and efficacy of antiviral drugs via targeting them to their specific sites of action [18].

Liposomes are attractive phospholipid-based vehicles that could encapsulate both hydrophilic and hydrophobic drugs. Nevertheless, the physical and chemical instability is the major limitation for the widespread application of this drug delivery system [19]. Niosomes are nanovesicles composed of non-ionic surfactants. They are more stable and less expensive alternative to liposomes. However, niosomes still have some physical instability shortcomings such as fusion, aggregation, and leaking problems [20].

Proniosomes are the provesicular form of niosomes that could be prepared as free-flowing powder in which the non-ionic surfactant is coated onto a hydrophilic carrier or as a liquid crystalline gel. Both types are converted into niosomal dispersion through reconstitution with water prior to use. There are various advantages of proniosomes over niosomes, including superior physical stability, protection of the entrapped drug from hydrolysis and higher convenience of transportation and storage [21]. Other researchers [22] studied the topical administration of Curcumin via formulation as a proniosomal gel. The current work investigated the formulation of dry proniosomal powder which is considered a promising platform that could provide unit dosing of drug in addition to improving its stability and solubility. Moreover, upon the addition of water, a niosomal suspension is formed which is suitable for administration by oral or other routes [23]. Besides, dry proniosomes are a free-flowing powder that can be further processed as beads, capsules, or tablets [24].

Molecular docking is an important strategy that could explain and predict the possible therapeutic effects of many drugs [25]. The molecular docking and virtual screening can mimic the actual biological systems [26] and could predict how two or more molecular structures (drug and protein or enzyme) interact together [27].

The present study seeks to formulate dry proniosomes of Curcumin as a controlled drug delivery carrier in order to improve the solubility and the stability of Curcumin in addition to investigating their cytotoxicity and antiviral activity in the treatment of HSV-1, which is supported by the molecular docking study. 


\section{Materials and Methods}

\subsection{Materials}

Curcumin, Polyoxyethylene (20) sorbitan monooleate (Tween 80), and cholesterol (CHOL) were obtained from Sigma Chemical Co. (St. Louis, MO, USA). Sorbitan monostearate (Span 60) was purchased from Oxford Lab Chemicals (Mumbai, India). Potassium monohydrogen phosphate and potassium dihydrogen phosphate were obtained from Alpha Chemica (Mumbai, India). Chloroform was obtained from El-Nasr Pharmaceutical Chemical Company (Cairo, Egypt). Spectra/Pore ${ }^{\circledR}$ dialysis membranes (Spectra/pore 4, 12,000-14,000 Mwt cut-off, diameter $16 \mathrm{~mm}$ ) were purchased from Spectrum Laboratories Inc. (Rancho Dominguez, CA, USA). HS-1 virus was kindly provided by Dr. R.G. Hughes (Roswell Park Memorial Institute, Buffalo, New York, NY, USA). Vero cells (African green monkey kidney cells, Vero C1008 [Vero 76, clone E6, Vero E6]) were purchased from Viromed Laboratories (Minnetonka, MN, USA). Dulbecco's modified Eagle's medium (DMEM), Penicillin G, and streptomycin sulfate were purchased from Sigma Chemical Co. (St. Louis, MO, USA). Calf serum was obtained from HyClone Laboratories, Inc. (Logan, UT, USA). All other chemicals and solvents were of analytical grade and used as received.

\subsection{Methods}

\subsubsection{HPLC Assay of Curcumin}

A validated HPLC procedure was performed using the Dionex UltiMate 3000RS HPLC system (Thermo ScientificTM, DionexTM, Sunnyvale, CA, USA) [10]. Chromeleon 7 was the software used for collecting and processing data. The Curcumin samples $(20 \mu \mathrm{L})$ were injected onto an Inertsil reversed-phase $\mathrm{C} 18(250 \times 4.6 \mathrm{~mm})$ column. The mobile phase was acetonitrile- $0.1 \%$ acetic acid at a ratio of $(60: 40, v / v \%)$. The samples were filtered through nylon membrane filters (Nylon Acrodisc, Gelman Sciences Inc., Ann Arbor, MI, USA). The elution was done at a flow rate of $1 \mathrm{~mL} / \mathrm{min}$. All measurements were done at room temperature. The wavelength of maximum absorption of Curcumin was $427 \mathrm{~nm}$.

\subsubsection{Preliminary Screening Studies}

The preliminary screening test was performed in order to select the proper hydration volume and the optimal hydration time for the reconstitution of proniosomes. Curcumin-loaded proniosomes have been prepared using Span 60 and 150:100 surfactant to CHOL $\mu$ molar ratio. The proniosomes were reconstituted using different hydration volumes (10 and $20 \mathrm{~mL}$ ) for different hydration times (5 and $30 \mathrm{~min}$ ). The prepared proniosomal formulations were evaluated for their EE\% that describes the integrity of the lipid bilayer and the absence of drug leakage.

\subsubsection{Preparation of Curcumin-Loaded Proniosomes}

Curcumin-loaded proniosomes were prepared by the slurry method [28,29]. Curcumin $(50 \mathrm{mg})$, the non-ionic surfactant and CHOL were dissolved in $10 \mathrm{~mL}$ chloroform. The slurry was formed by introducing the lipid mixture into a 100-mL round-bottom flask containing $250 \mathrm{mg}$ maltodextirn. The organic solvent was evaporated using a rotary evaporator (Buchi rotavapor R-3000, Flawil, Switzerland) that was adjusted to $100 \mathrm{rpm}$ at $60 \pm 2{ }^{\circ} \mathrm{C}$ under reduced pressure of $16 \mathrm{~mm} \mathrm{Hg}$. The evaporation process was continued until the content in the round-bottom flask becomes completely dry powder. The Curcumin-loaded proniosomes were stored in a tightly closed container to be used for further studies.

\subsubsection{Experimental Design}

Nine Curcumin proniosomes were optimized according to a $3^{2}$ factorial design using Design-Expert software, Version 7.0.0 (Stat-Ease, Inc., Minneapolis, MN, USA) to demonstrate the impact of the 
independent variables on different responses [30]. The ratio of surfactant to $\mathrm{CHO}$ and type of surfactant were considered as the independent variables $X 1$ and $X 2$, respectively. The entrapment efficiency $(\mathrm{EE} \%, \mathrm{Y} 1)$ and the percentage of Curcumin released after $12 \mathrm{~h}\left(\mathrm{Q}_{12 \mathrm{~h}}, \mathrm{Y} 2\right)$ were selected as the dependent variables. Each factor was screened at three levels $(-1,0$, and +1$)$ that labeled the lower, the middle, and the upper levels, respectively.

The coefficient of determination $\left(\mathrm{R}^{2}\right)$, predicted $\mathrm{R}^{2}$ and adjusted $\mathrm{R}^{2}$ were estimated in addition to plotting diagnostic plots for both $E E \%$ and $Q_{12 h}$ in order to demonstrate the goodness of fit of the present model to the experimental results. The statistical analysis of the data was performed by the analysis of variance (ANOVA) for estimation of the significance level of each term according to the $p$-value and F-statistics [31].

\subsubsection{Preparation of Proniosome-Derived Niosomal Dispersions of Curcumin}

The niosomal dispersion of Curcumin was fabricated by hydrating the previously prepared proniosomal powder using phosphate buffer $(\mathrm{pH}=7.4)$ at $60{ }^{\circ} \mathrm{C} \pm 2{ }^{\circ} \mathrm{C}$ (The time and volume of hydration were determined according to the preliminary test). The dispersion was agitated using a vortex mixer (BOECO, Hamburg, Germany) and then sonicated for 5 min using a bath sonicator (Elmasonic E 30 H, Elma, Singen, Germany). The resultant niosomal dispersion was left overnight at $4{ }^{\circ} \mathrm{C}$ in a refrigerator for complete maturation to be used for further studies [32].

\subsubsection{In Vitro Characterization of Curcumin-Loaded Proniosomes}

\section{Determination of Drug Content and EE\% of Curcumin-Loaded Proniosomes}

EE\% of Curcumin-loaded proniosomes was estimated by the indirect method. The free (un-entrapped) Curcumin was separated by the ultracentrifugation method. A 1-mL aliquot of proniosome-derived niosomal dispersions of Curcumin was centrifuged using a cooling ultracentrifuge at $4{ }^{\circ} \mathrm{C}$ (Biofuge, primo Heraeus, Burladingen, Germany) at 14,000 rpm for $1 \mathrm{~h} \mathrm{[33].} \mathrm{The} \mathrm{supernatant} \mathrm{was}$ filtered through a 0.20- $\mu \mathrm{m}$ nylon membrane filter (Nylon Acrodisc, Gelman Sciences Inc., Ann Arbor, MI, USA) and analyzed for its drug content using HPLC at $427 \mathrm{~nm}$. Encapsulation efficiency was calculated as follows:

$$
\mathrm{EE}(\%)=(\mathrm{Ci}-\mathrm{Cs}) \times 100 / \mathrm{C}
$$

where $\mathrm{Ci}=$ Initial amount of Curcumin, $\mathrm{Cs}=$ Amount of Curcumin in the supernatant.

The total drug content of Curcumin (unentrapped + entrapped) was determined by disrupting $1 \mathrm{~mL}$ of the proniosome-derived niosomal dispersion with $100 \mathrm{~mL}$ isopropyl alcohol [34]. The samples were filtered using a $0.20 \mu \mathrm{m}$ nylon membrane filter (Nylon Acrodisc, Gelman Sciences Inc., USA) and analyzed for drug content using HPLC at $427 \mathrm{~nm}$.

\section{In Vitro Release Study of Curcumin-Loaded Proniosomes}

The in vitro release study of Curcumin-loaded proniosomes was demonstrated by the dialysis method using a glass cylinder which is attached to the dissolution apparatus shaft (USP apparatus II, Erweka DT-720, Kreuzau, Germany) [17,35,36]. Initially, the semi-permeable cellulose membrane was hydrated using a phosphate buffer solution of $\mathrm{pH}=7.4$ [10] at $25^{\circ} \mathrm{C}$ for $24 \mathrm{~h}$. To maintain the sink condition, $0.5 \%(w / v)$ SLS was added to phosphate buffer, $\mathrm{pH}=7.4$, and used as the dissolution medium [37]. The receptor chamber contained $100 \mathrm{~mL}$ of dissolution medium which was kept at $37 \pm 0.5^{\circ} \mathrm{C}$, to simulate the in vivo conditions, and stirred at $50 \mathrm{rpm}$. The prehydrated cellulose membrane was mounted between the donor and receptor compartments. $1 \mathrm{~mL}$ of the proniosome-derived niosomal dispersion containing entrapped Curcumin was placed over the cellulose membrane in the donor chamber. A $200-\mu \mathrm{L}$ aliquot was withdrawn at different time intervals and replenished by the same volume of fresh buffer solution to retain a constant volume of the receptor medium [30]. Triplicate measurements were performed and the withdrawn samples were filtered using a $0.20-\mu \mathrm{m}$ membrane filter and analyzed for their drug content by HPLC at $427 \mathrm{~nm}$. The data are 
expressed as mean $\%$ Curcumin released \pm SD. The release profiles of the reconstituted proniosomal formulations were plotted by taking the \% Curcumin released as the Y-axis and time as the X-axis.

Different mathematical models (zero-order, first-order, the Higuchi diffusion model, Korsmeyer-Pappas, and Hixson Crowell equation) were used to describe the mechanism of in vitro release and the proper kinetic model of Curcumin-loaded proniosomes. The highest coefficient of determination value $\left(\mathrm{R}^{2}\right)$ denoted the order of in vitro drug release [38].

Statistical Optimization of Curcumin-Loaded Proniosomes

The optimized Curcumin-loaded proniosomal formula was determined on the basis of the desirability function that describes the closeness of different responses to their optimal values [39]. The optimized formula was chosen on the basis of maximum EE\% and maximum $\mathrm{Q}_{12 \mathrm{~h}}$. The formulation that has the highest desirability value is selected as the optimized formula because it has the most desirable responses. The optimized formula was also validated by calculation of $\%$ relative error by comparing the observed values of different responses, \%EE and $Q_{12}$, with their predicted values as follows [40]:

$$
\% \text { Relative error }=\frac{(\text { predicted value }- \text { observed value }) \times 100}{\text { predicted value }}
$$

The optimized Curcumin-loaded proniosomal formula was subjected to further characterization tests.

2.2.7. Comparative Study of the Optimized Curcumin-Loaded Proniosomal Formula and the Conventional Niosomes

A comparative study was performed between the optimized Curcumin-loaded proniosomal formula and the corresponding niosomes by determination of $E E \%, Q_{12 h}$ and stability test.

Formulation of Curcumin-Loaded Niosomes

The thin-film hydration method [41] was used for formulating the corresponding niosomal dispersion. Briefly, Curcumin (50 mg), the non-ionic surfactant and CHOL, at the chosen concentrations, were dissolved in chloroform $(10 \mathrm{~mL})$ in a round bottom flask. Chloroform was then evaporated at $60 \pm 2{ }^{\circ} \mathrm{C}$ under reduced pressure of $16 \mathrm{~mm} \mathrm{Hg}$ using a rotary evaporator (Buchi rotavapor R-3000, Flawil, Switzerland) forming a thin lipid film on the flask walls. The thin film was rehydrated by phosphate buffer, $\mathrm{pH} 7.4(10 \mathrm{~mL})$ at $60 \pm 2{ }^{\circ} \mathrm{C}$ for $30 \mathrm{~min}$. The niosomal dispersion was agitated using a vortex mixer (BOECO, Hamburg, Germany) and then sonicated for 5 min using a bath sonicator (Elmasonic E $30 \mathrm{H}$, Elma, Singen, Germany). The niosomal dispersion was stored overnight at $4{ }^{\circ} \mathrm{C}$ for complete maturation.

Evaluation of EE\% and In Vitro Release of Curcumin-Loaded Niosomes

Both $\mathrm{EE} \%$ and the in vitro release of Curcumin-loaded niosomes were tested as previously described.

The Stability Test

The stability test was used to study the impact of storage on the optimized Curcumin-loaded proniosomal formula and the corresponding niosomes. Both formulations were placed in a tightly closed glass vial at $\left(4-8{ }^{\circ} \mathrm{C}\right)$ for three months [42]. The formulations were evaluated with regard to their drug content, $\mathrm{EE} \%$, and $\mathrm{Q}_{12 \mathrm{~h}}$. The significance of difference, between the fresh and the stored formulations, was estimated by Student's t-test using SPSS-11 software (SPSS. Inc., Chicago, IL, USA).

Moreover, the in vitro release profile of the stored formulations was compared to that of the fresh preparations by the similarity factor test $[38,43]$. The $\mathrm{f} 2$ was calculated according to the following equation:

$$
\mathrm{F} 2=50 . \log \left\{\left[1+\frac{1}{n} \sum_{t=1}^{n}(\mathrm{Rt}-\mathrm{Tt})^{2}\right]^{-0.5}\right\} 100
$$


where $\mathrm{n}$ is the number of sampling points and $\mathrm{R}_{\mathrm{t}}$ and $\mathrm{T}_{\mathrm{t}}$ are the $\%$ Curcumin released from the fresh and the stored formula, respectively, at time $t$. If the $\mathrm{f}_{2}$ value lies between 50 and 100 , the two release profiles are considered to be similar.

\subsubsection{Characterization of the Optimized Curcumin-Loaded Proniosomes}

\section{Scanning Electron Microscopy (SEM)}

The morphology of the reconstituted Curcumin-loaded proniosomal formula was investigated using a scanning electron microscope (JSM 6100 JEOL, Tokyo, Japan). $0.1 \mathrm{~mL}$ of the optimized formula was diluted by $10 \mathrm{~mL}$ of deionized water. One drop of the diluted Curcumin-loaded niosomal dispersion was placed onto a SEM sample stub using a carbon adhesive tape. Afterward, the sample was and dried and scanned by SEM [44].

Vesicle size and Zeta Potential Determination

The size and zeta potential of the Curcumin-loaded nanovesicles were determined for the investigation of the colloidal characteristics of the reconstituted proniosomal formula. The reconstituted proniosomal formula $(0.1 \mathrm{~mL})$ was properly diluted with deionized water $(10 \mathrm{~mL})$. The NICOMP 380 ZLS zeta potential/particle sizer (PSS Nicomp, Santa Barbara, CA, USA), with a scattering angle of $90^{\circ}$, was then used to estimate vesicle size and zeta potential [45] at $25^{\circ} \mathrm{C}$. Triplicate measurements were performed.

\section{Determination of the Micromeritic Properties}

The micromeritic properties of the optimized proniosomal powder and maltodextrin were determined by calculating the angle of repose of powders using the funnel method. The tested powders were poured through a funnel so that its outlet orifice is $5 \mathrm{~cm}$ above the surface of a graph paper. The powders flowed down forming a cone on the graph paper [46]. The angle of repose was estimated as follows:

$$
\operatorname{Tan} \theta=\mathrm{h} / \mathrm{r}
$$

( $\theta$ is the angle of repose, $\mathrm{h}$ is the height of the powder cone, and $\mathrm{r}$ is the radius of the base of powder cone).

\subsubsection{Evaluation of the Antiviral Activity and Cytotoxicity}

The antiviral activity of the reconstituted proniosomal formula was tested against the HS-1 virus which was grown on Vero (African green monkey kidney) cells. The cytotoxicity and antiviral activity of the proniosomal formula were compared with that of the corresponding Curcumin dispersion. Additionally, the antiviral activity and cytotoxicity of ACV dispersion were studied in the presence and absence of the optimized proniosomal formula.

\section{HS-1 Virus and the Cell Culture}

HS-1 virus stocks were prepared as culture medium aliquots from Vero cells infected with a multiplicity of 1 virion/10 cells and cultured for 3 days and stored at $\left(-80^{\circ} \mathrm{C}\right)$ until used. Preparing the working stocks was performed by titering virus through serial dilution in the culture medium. They were assayed, in triplicate, on Vero monolayers in the wells of microtiter trays (Falcon Microtest III 96-wells trays, Becton Dickinson Labware, Lincoln Park, NJ, USA) [47].

Vero cells were grown in DMEM supplemented with $10 \% v / v$ calf serum, Penicillin G $(60 \mu \mathrm{g} / \mathrm{mL})$ and streptomycin sulfate $(100 \mu \mathrm{g} / \mathrm{mL})$ and kept in a humidified atmosphere containing $\mathrm{CO}_{2}(15 \% v / v)$ in air at $37^{\circ} \mathrm{C}$. Vero stocks were maintained in culture flasks containing medium supplemented with $1 \%$ $v / v$ calf serum at $34^{\circ} \mathrm{C}$. Subcultures, for both antiviral screening and virus titration, were grown in the wells of microtiter trays through suspending Vero cells in medium following trypsin-EDTA treatment. 
That was followed by counting the suspension using a hemocytometer, diluting in medium containing $10 \% v / v$ calf serum to $2 \times 10^{4}$ cells $/ 200 \mathrm{~mL}$ culture, aliquoting into different wells of the tray, and finally culturing until reaching confluency [48].

\section{Determination of the Antiviral Activity}

The antiviral activity was studied using an improved plaque-reduction assay [4,49]. Microtiter trays having confluent monolayer cultures of Vero cells were inverted. The medium was shaken out and then replaced with serial dilutions of the samples (in triplicate) in a $100-\mu \mathrm{L}$ medium followed by titering virus into $(100-\mu \mathrm{L}$ medium containing $10 \% v / v$ calf serum) in different wells. The last row of wells was kept for the control that was not treated with samples or HS-1 virus. Different trays were cultured for $66 \mathrm{~h}$. After the appropriate incubation period, the trays were inverted on pads of paper towels. The remaining cells were rinsed well using medium and fixed, for about $20 \mathrm{~min}$, using formaldehyde $(3.7 \% v / v)$ in saline and stained with crystal violet $(0.4 \%)$. The improved plaque-reduction assay investigated the efficacy of the tested agents on the inhibition of HS-1 viral infection of Vero cells via determination of the \% reduction in the number of viral plaques when compared with the untreated group. The viral particles which are not neutralized by the tested agents would infect the cells forming a plaque. The cytotoxicity was assessed as the concentration that achieved a fifty percent loss of the monolayer present around the plaques caused by HS-1 virus $\left(\mathrm{CC}_{50}\right)$ [47].

\subsubsection{Statistical Analysis}

Statistical analysis was conducted by one-way ANOVA and the Student's t-test using SPSS-11 software (SPSS. Inc., Chicago, IL, USA). Investigating the impact of different independent variables on $\mathrm{EE} \%$ and $\mathrm{Q}_{12 \mathrm{~h}}$ of the Curcumin-loaded proniosomal formulations was performed by ANOVA using Design-Expert software, Version 7.0.0 (Stat-Ease, Inc., Minneapolis, MN, USA). A p-value lower than 0.05 describes statistically significant differences.

\section{Results and Discussion}

\subsection{Preliminary Screening Studies}

The preliminary screening test is an important tool that is used for the determination of the most suitable parameters for the pharmaceutical formulation. The reconstitution of proniosomes into niosomes is a vital factor that could affect the encapsulation efficiency of the proniosomal vesicles [34]. Therefore, both the time and the volume of hydration were studied to select the proper conditions for the reconstitution of proniosomes (Table 1). The results investigated that the volume of the hydration had a significant negative impact $(p<0.05)$ on $\mathrm{EE} \%$. These findings could be attributable to increased leakage of the drug from niosomal vesicles at larger hydration volume [34]. However, the time of hydration had no significant effect $(p>0.05)$ on $\% \mathrm{EE}$. These results are in accordance with Pawar et al. who reported that there was no significant influence of the time of hydration on the EE\% of niosomal vesicles [50]. Therefore, $5 \mathrm{~min}$ hydration time is selected for further studies because short hydration time would improve patient acceptability and product applicability. Other researchers such as Sammour et al. [34] reported that the hydration time has a significant $(p<0.05)$ negative effect on $\%$ EE. However, Ruckmani and Sankar found that more drug would be entrapped within the vesicles at longer hydration time [51].

According to the preliminary screening test, $10 \mathrm{~mL}$ hydration volume and $5 \mathrm{~min}$ hydration time were selected for the reconstitution of proniosomes. 
Table 1. The prescreening study for formulation of Curcumin-loaded proniosomes.

\begin{tabular}{cccc}
\hline Formula & Time of Hydration $(\mathbf{m i n})$ & Volume of Hydration $(\mathbf{m L})$ & ${ }^{*} \mathbf{E E} \%$ \\
\hline P1 & 5 & 10 & $94.11 \pm 1.27$ \\
P2 & 5 & 20 & $82.13 \pm 2.11$ \\
P3 & 30 & 10 & $94.23 \pm 1.27$ \\
P4 & 30 & 20 & $82.30 \pm 1.32$ \\
\hline
\end{tabular}

Notes: $1 \mathrm{~g}$ of maltodextrin per 1 mmole of the total lipid-surfactant mixture; ${ }^{*}$ the values are presented as mean \pm SD $(n=3)$. Abbreviations: EE, entrapment efficiency.

\subsection{Formulation of Curcumin-Loaded Proniosomes}

Curcumin-loaded proniosomes have been prepared using the slurry method. The main constituents of proniosomes are a surfactant, a hydrophilic carrier, and a membrane stabilizer. The involved excipients are FDA approved excipients [52] and generally recommended as safe (GRAS) [53]. Span 60, Tween 80 , and a mixture of the two surfactants have been used as the non-ionic surfactants. Non-ionic surfactants are used in the preparation of the proniosomal vesicles due to their safety, compatibility and stability [54]. CHOL has been added as a membrane stabilizer of the nanovesicles. Its addition improves the stability of the lipid bilayer by increasing the gel liquid transition temperature of the vesicle [17]. Hydrophilic carriers increase the surface area, impart flexibility in the ratio of surfactant and other constituents, and provide more efficient loading [55]. Maltodextrin was selected as the coating carrier due to its safety and good aqueous solubility for ease of reconstitution. Moreover, maltodextrin has poor solubility in chloroform that permits easy coating of the maltodextrin particles after adding the surfactant solution and then evaporating the solvent [56].

\subsection{Reconstitution of Curcumin-Loaded Proniosomes into Niosomes}

Curcumin-loaded proniosomes were reconstituted by hydrating the proniosomal powder with phosphate buffer $(\mathrm{pH}=7.4)$ at $60 \pm 2{ }^{\circ} \mathrm{C}$ [57]. The addition of water results in swelling of the lipid bilayer due to the interaction between the hydrophilic groups of the surfactants and water leading to the development of multilamellar and spherical shaped vesicles [17]. The multi-lamellar vesicles are further transformed into unilamellar niosomal vesicles by sonication [58].

The formulation of niosomal dispersions by the reconstitution of proniosomal powder is more convenient than other conventional methods for preparing niosomes. That could be explained on the basis of the higher stability of the proniosomal powder compared to the corresponding niosomes [59]. Moreover, coating the surfactant film on the carrier surface, instead of the inner wall of the round bottom flask, results in the formation of a thinner film onto a wider surface. Therefore, niosomal vesicles, with high drug loading capacity, are developed through easy hydration of this film [60].

The preparation of niosomes via standard techniques results in the formation of unstable heterogeneous dispersion that is prone to aggregation or sedimentation. Additionally, the complete hydration of the lipid film is difficult even after vigorous shaking. Sometimes, a lipid residue remains on the round bottom flask wall, and additional time is needed. Upon hydration, this layer becomes more viscous and tends to remain adhered to the flask wall. As a result, the loss of some lipids during the formulation process is possible [61].

Other researchers such as Abd-Elbary et al. [62] compared the characteristics of the reconstituted proniosomes with the corresponding niosomal vesicles. The conventional niosomes were found to be larger and more heterogeneous than reconstituted proniosomes.

\subsection{Analysis of the $3^{2}$ Factorial Design}

The objective of the optimization process is to explore the effects of different variables on the characteristics of the formulation and to determine the levels of variables required for the development of high-quality products [63]. For the optimization of Curcumin-loaded proniosomes, a $3^{2}$ factorial design was used (Table 2). Two independent variables have been chosen: the ratio of surfactant to 
CHOL (X1) and the type of surfactant (X2). The selection of the optimized proniosomal formula was on the basis of maximizing both EE\% (Y1) and $\mathrm{Q}_{12 \mathrm{~h}}(\mathrm{Y} 2)$.

Table 2. Dependent and independent variables in $3^{2}$ factorial design used for the optimization of Curcumin-loaded proniosomes.

\begin{tabular}{|c|c|c|c|c|c|}
\hline \multirow{3}{*}{ Formula Code } & \multicolumn{5}{|c|}{ Variables } \\
\hline & \multicolumn{2}{|c|}{ Independent } & \multicolumn{3}{|c|}{ Dependent } \\
\hline & $\mathbf{X 1}$ & $\mathrm{X} 2$ & $\mathbf{Y} 1 *$ & \multicolumn{2}{|l|}{$\mathrm{Y} 2 *$} \\
\hline F1 & -1 & -1 & $89.06 \pm 2.12$ & \multicolumn{2}{|c|}{$51.74 \pm 1.23$} \\
\hline F2 & -1 & 0 & $81.11 \pm 1.36$ & \multicolumn{2}{|c|}{$76.56 \pm 1.41$} \\
\hline F3 & -1 & 1 & $68.61 \pm 1.62$ & \multicolumn{2}{|c|}{$92.52 \pm 2.69$} \\
\hline $\mathrm{F} 4$ & 0 & -1 & $94.11 \pm 1.27$ & \multicolumn{2}{|c|}{$42.71 \pm 1.74$} \\
\hline F5 \# & 0 & 0 & $89.94 \pm 2.31$ & \multicolumn{2}{|c|}{$70.89 \pm 1.62$} \\
\hline F6 & 0 & 1 & $70.11 \pm 1.49$ & \multicolumn{2}{|c|}{$89.76 \pm 1.44$} \\
\hline F7 & 1 & -1 & $81.89 \pm 1.25$ & \multicolumn{2}{|c|}{$61.78 \pm 1.38$} \\
\hline F8 & 1 & 0 & $69.17 \pm 1.41$ & \multicolumn{2}{|c|}{$84.26 \pm 1.34$} \\
\hline F9 & 1 & 1 & $60.33 \pm 1.61$ & \multicolumn{2}{|c|}{$94.91 \pm 2.18$} \\
\hline \multicolumn{3}{|c|}{ Independent variables } & Low $(-1)$ & Medium (0) & $\operatorname{High}(+1)$ \\
\hline \multirow{2}{*}{\multicolumn{3}{|c|}{$\begin{array}{l}\text { X1: Ratio of surfactant to CHOL } \\
\text { X2: Type of surfactant }\end{array}$}} & $90: 160$ & $150: 100$ & 210:40 \\
\hline & & & Span 60 & Span 60 \& Tween 80 & Tween 80 \\
\hline
\end{tabular}

Notes: Y1: EE (\%), Y2: $\mathrm{Q}_{12 \mathrm{~h}}(\%),{ }^{*}$ the data are expressed as mean $\pm \mathrm{SD}(\mathrm{n}=3)$, \# Optimized Formula, $1 \mathrm{~g}$ of maltodextrin per 1 mmole of the surfactant-lipid mixture. Abbreviations: $\mathrm{Q}_{12 \mathrm{~h}}$, drug released after $12 \mathrm{~h}$; EE, entrapment efficiency; $\mathrm{CHOL}$, cholesterol.

Table 3 summarizes the output data of the factorial design of Curcumin-loaded proniosomes. The adequate precision measures the signal to noise ratio. In this model, adequate precision values of both responses were more than 4 (the desired value) demonstrating that the model is capable of navigating the design space. Data of both responses ( $\mathrm{Y} 1$ and $\mathrm{Y} 2$ ) provided a reasonable fit to the linear model $\left(R^{2}=0.9676\right.$ and 0.9822 , respectively). The relatively high values of $R^{2}$, predicted $R^{2}$, and adjusted $R^{2}$ of both responses showed that the obtained equations are statistically valid and fit to the obtained results. The predicted $\mathrm{R}^{2}$ estimates the response value predictability of the model. In addition, the predicted and adjusted $\mathrm{R}^{2}$ values are in reasonable agreement, because the difference between them is lower than 0.20 [64].

Table 3. Output data of the $3^{2}$ factorial design of Curcumin-loaded proniosomes.

\begin{tabular}{lcccc}
\hline Responses & $\mathbf{R}^{\mathbf{2}}$ & Adjusted $\mathbf{R}^{\mathbf{2}}$ & Predicted $\mathbf{R}^{\mathbf{2}}$ & Adequate Precision \\
\hline $\mathrm{EE} \%(\mathrm{Y} 1)$ & 0.9676 & 0.9352 & 0.8359 & 16.372 \\
$\mathrm{Q}_{12 \mathrm{~h}}(\mathrm{Y} 2)$ & 0.9822 & 0.9643 & 0.9097 & 20.165
\end{tabular}

Abbreviations: $\mathrm{R}^{2}$, the coefficient of determination; $\mathrm{Q}_{12 \mathrm{~h}} \%$ drug released after $12 \mathrm{~h}$; EE, entrapment efficiency.

Besides, diagnostic plots for both $\mathrm{EE} \%$ and $\mathrm{Q}_{12 \mathrm{~h}}$ were developed to ensure the goodness of fit of the present model and to assess its credibility, Figures 1 and 2, respectively. The residuals were computed as the difference between the actual and predicted values of the responses. The normal probability plots of residuals, Figures $1 \mathrm{a}$ and $2 \mathrm{a}$, demonstrate a linear pattern with a normal distribution of the residuals, and hence, the data need no transformation. A plot of the residuals versus the predicted responses, Figures $1 \mathrm{~b}$ and $2 \mathrm{~b}$, exhibit that the color points depicting the values of both responses were scattered randomly and located within the limits near to the zero-axis investigating the absence of constant error. Figures $1 \mathrm{c}$ and $2 \mathrm{c}$ represent the residual versus run plots and describe a uniform and random scattering of points, showing that no lurking variables affect the studied responses. Figures $1 \mathrm{~d}$ and $2 \mathrm{~d}$ investigated the excellent analogy between the observed and the predicted values of $\mathrm{Y} 1$ and $\mathrm{Y} 2$ of Curcumin-loaded proniosomes in the current model. 
a

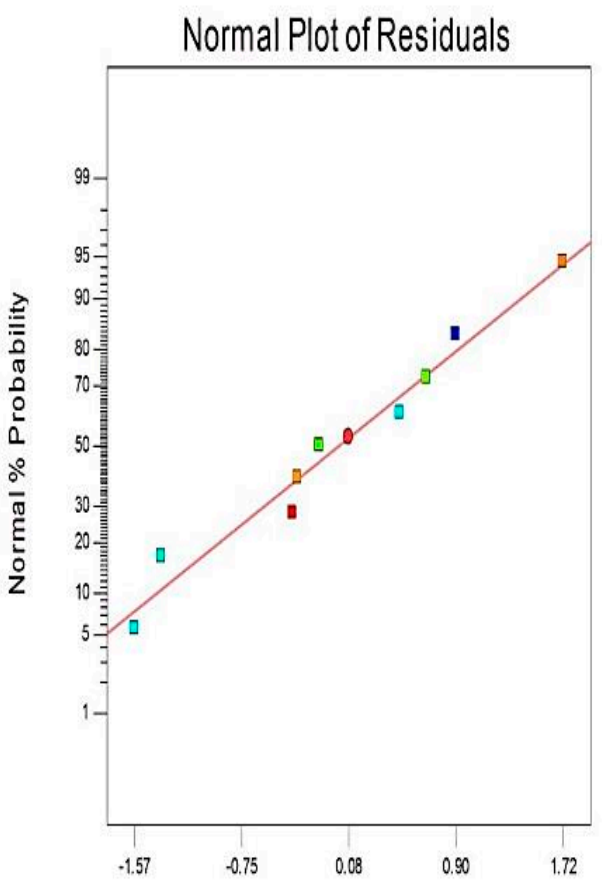

Internally Studentized Residuals

c

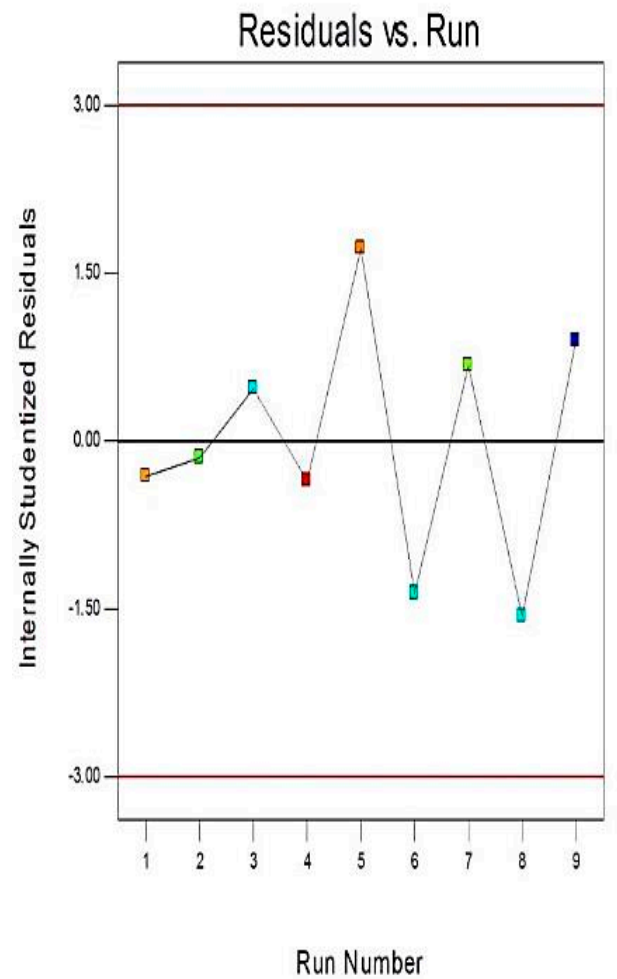

b

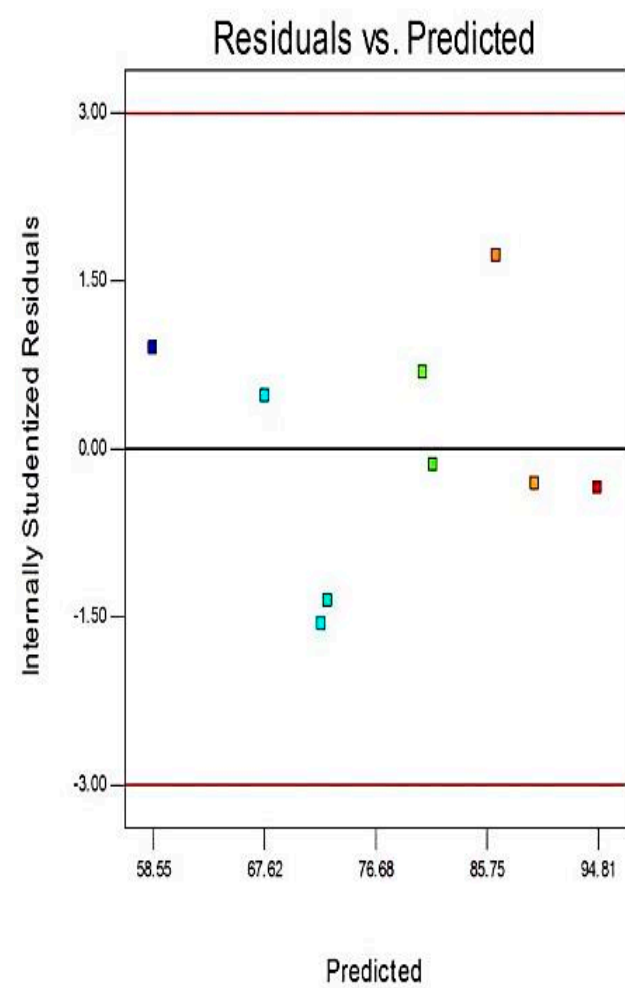

d

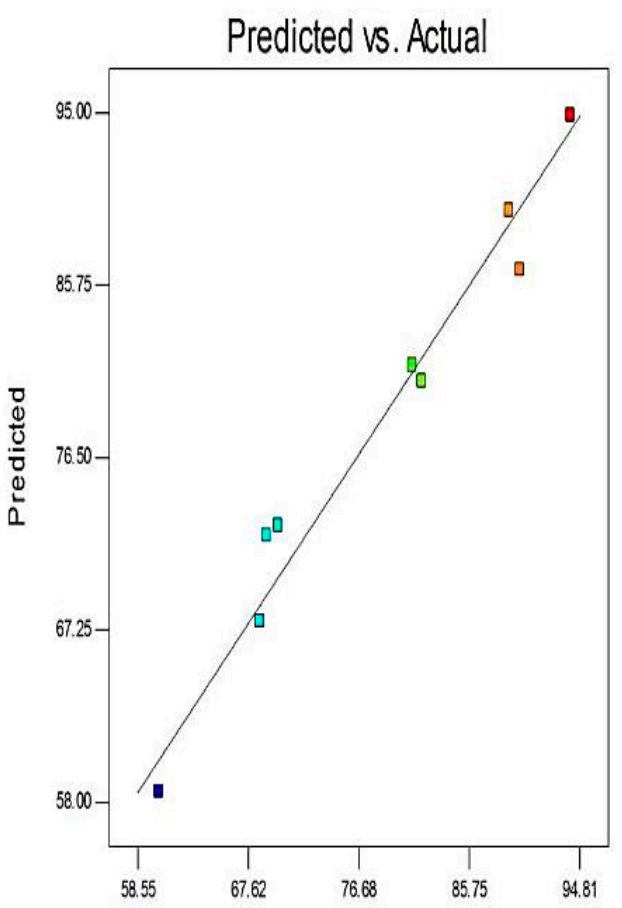

Actual

Figure 1. The diagnostic plots for entrapment efficiency (EE)\% of Curcumin-loaded proniosomes (a) normal probability plot (b). internally studentized residuals versus predicted values plot, (c) internally studentized residuals versus run number plot and (d) predicted versus actual values plot. Abbreviation: EE, entrapment efficiency. 
a

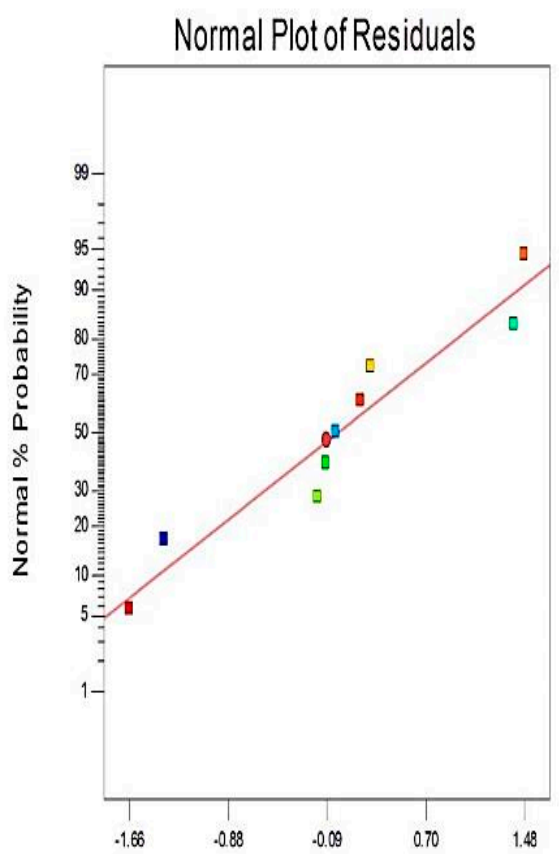

Internally Studentized Residuals

c

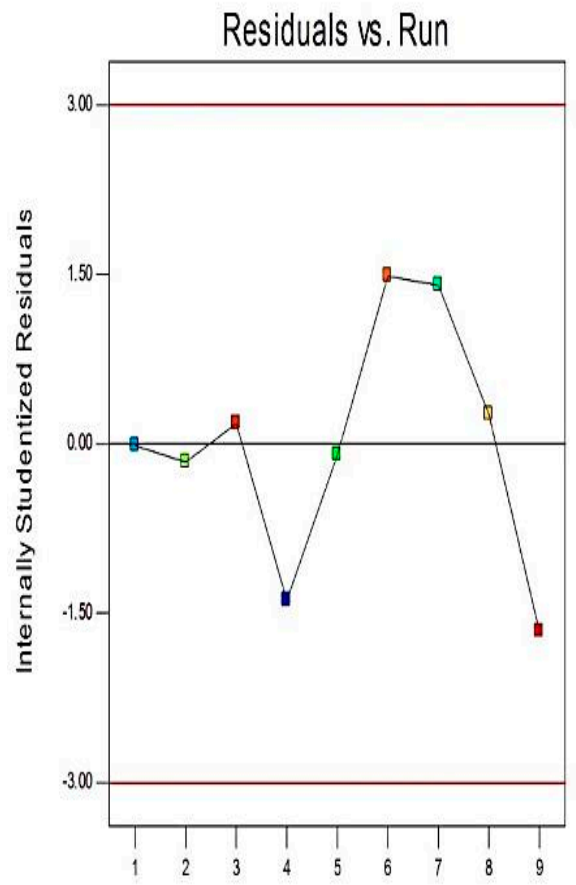

b

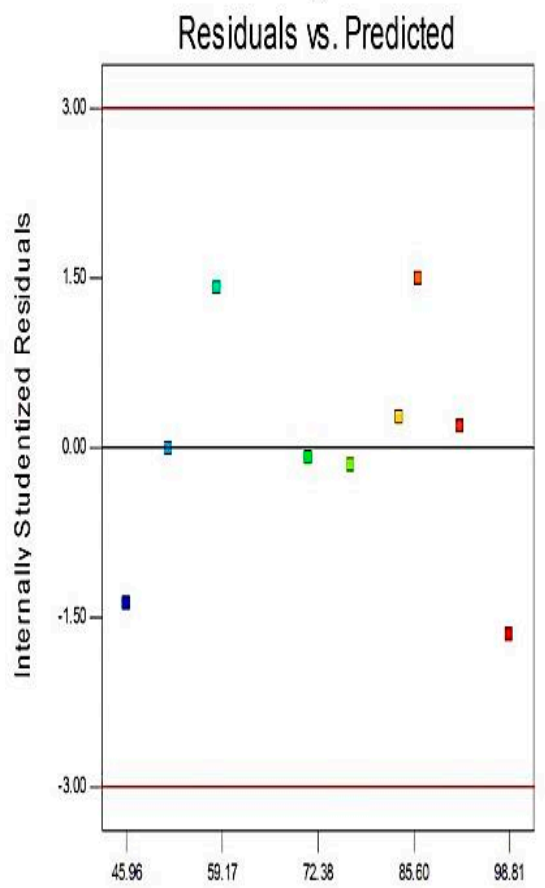

Predicted

d

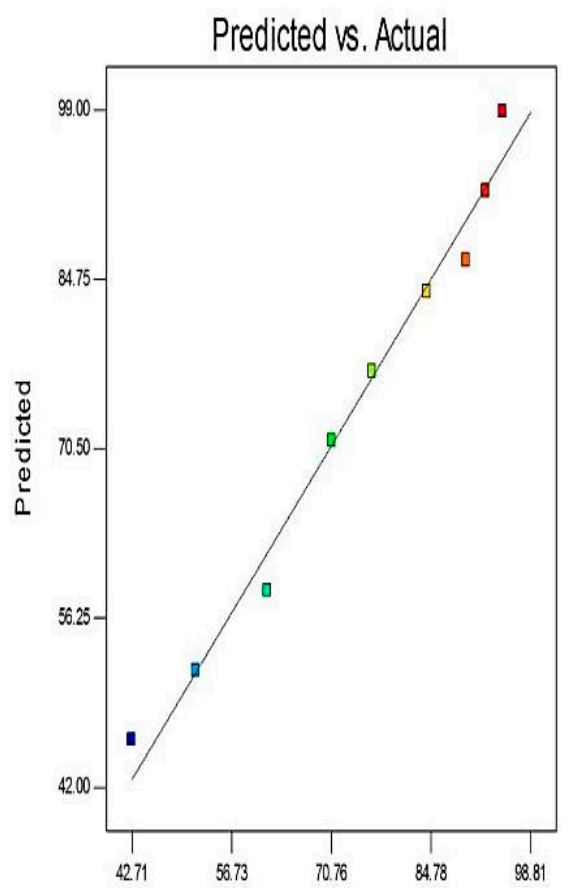

Run Number

Actual

Figure 2. The diagnostic plots for $\mathrm{Q}_{12 \mathrm{~h}}$ of Curcumin-loaded proniosomes; (a) normal probability plot, (b) internally studentized residuals versus predicted values plot, (c) internally studentized residuals versus run number plot, and (d) predicted versus actual values plot. Abbreviation: $\mathrm{Q}_{12 \mathrm{~h}} \% \mathrm{drug}$ released after $12 \mathrm{~h}$. 
ANOVA study demonstrates the significance of the influence of different independent variables on both responses (Y1 and Y2). When the $p$-value is less than 0.05 , the null hypothesis $\left(\mathrm{H}_{0}\right)$ is dismissed and the alternate hypothesis is accepted (Table 4).

Table 4. ANOVA for the $3^{2}$ factorial design of Curcumin-loaded proniosomes.

\begin{tabular}{ccccccc}
\hline Depndent Variable & Source & SS & DF & MS & F-Value & $p$-Value \\
\hline & Model & 1053.93 & 4 & 263.48 & 29.84 & 0.0031 \\
Y1 & X1 & 312.89 & 2 & 156.45 & 17.72 & 0.0103 \\
& X2 & 471.03 & 2 & 370.52 & 41.97 & 0.0021 \\
& Model & 2724.45 & 4 & 681.11 & 55.09 & 0.0009 \\
Y2 & X1 & 235.90 & 2 & 117.95 & 9.54 & 0.0300 \\
& X2 & 2488.55 & 2 & 1244.28 & 100.64 & 0.0004
\end{tabular}

Notes: Y1: EE (\%), Y2: $\mathrm{Q}_{12 \mathrm{~h}}(\%)$, ratio of surfactant to CHOL (X1), the surfactant type $(\mathrm{X} 2), p$-value less than 0.05 shows that the model terms are significant. Abbreviation: SS, sum of squares; DF, degree of freedom; MS, mean of squares.

\subsubsection{The Effect of Formulation Variables on EE\% of Curcumin-Loaded Proniosomes}

The drug content (entrapped + un-entrapped) of Curcumin-loaded proniosomes ranged from $95.26 \pm 1.33$ to $103.56 \pm 1.69 \%$. Table 2 demonstrates that the EE\% of Curcumin-loaded proniosomes ranged from $60.33 \pm 1.61$ to $94.11 \pm 1.27 \%$. Figure 3 investigates the impact of different variables on the EE\% of Curcumin-loaded proniosomes. The statistical analysis (Table 4) confirms that both the ratio of surfactant to CHOL and the type of surfactant have a significant influence on \%EE.

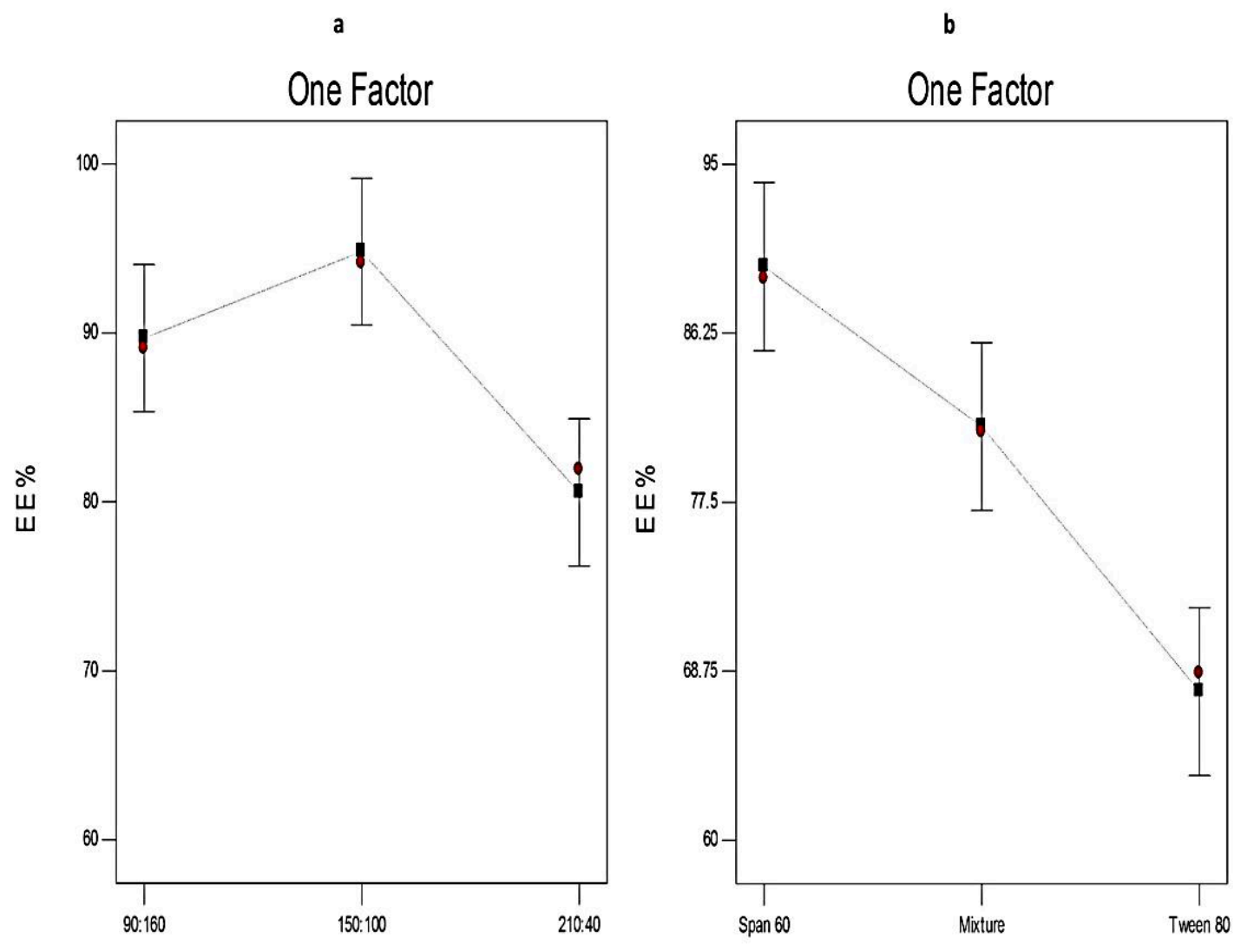

Figure 3. The effect of different independent variables (a) ratio of surfactant to cholesterol (CHOL) and (b) type of surfactant on EE\% of Curcumin-loaded proniosomes according to $3^{2}$ factorial design. Abbreviation: CHOL, cholesterol; EE, entrapment efficiency. 
Concerning the ratio of surfactant to $\mathrm{CHOL}(\mathrm{X} 1)$, it is clear that increasing the $\mathrm{CHOL}$ concentration has a significant impact on the EE\% of Curcumin-loaded proniosomes $(p<0.05)$. EE\% increased significantly when the amount of CHOL increased from $40 \mathrm{mg}$ to $100 \mathrm{mg}$. That may be attributable to the fact that $\mathrm{CHOL}$ could increase the rigidity of the lipid bilayer by acting as a vesicular cement [51]. However, the EE\% decreased with further increase in $\mathrm{CHOL}$ concentration. This might be due to its competition with the drug for the packing space within the lipid bilayer and disrupting the regular structure of the lipid membrane. These outcomes were in agreement with El-Laithy et al. [65] and Sambhakar et al. [42] who reported that increasing the concentration of CHOL in the proniosomal formulations facilitates the development of less leaky bilayers due to its intercalation between the non-ionic surfactants bilayers. Conversely, a further increase in $\mathrm{CHOL}$ concentrations results in decreasing the $\% \mathrm{EE}$.

With respect to the type of surfactant (X2), it is obvious that X2 had a significant impact on \%EE $(p<0.01)$. The EE\% from different formulations prepared using different types of surfactants followed the order of; Tween 80-based vesicles $<$ mixed surfactant-based vesicles $<$ Span 60 -based vesicles. That could be attributable to the development of less leaky nanovesicles upon using Span 60 that has higher hydrophobicity (HLB 4.7) and higher phase transition temperature $\left(53^{\circ} \mathrm{C}\right)$ compared to Tween 80. Conversely, Tween 80 is a hydrophilic surfactant with a high HLB value (HLB 15) and contains a double bond in its alkyl chain that hinders the development of a tight membrane and leads to the formation of more leaky vesicles $[51,66]$.

These results are in accordance with Eldeeb et al. [67] who studied the optimal conditions for the formulation of brimonidine tartrate-loaded proniosomes and found that the EE\% of Span 60-based proniosomes was higher than Tween 80-based ones.

\subsubsection{The Effect of Formulation Variables on $\mathrm{Q}_{12 \mathrm{~h}}$ of Curcumin-Loaded Proniosomes}

Figure 4 demonstrates that the $\mathrm{Q}_{12 \mathrm{~h}}$ of different Curcumin-loaded proniosomes ranged from $42.71 \pm 1.74$ to $94.91 \pm 2.18 \%$. It is obvious that the release of Curcumin from different proniosomal formulations was more prolonged than the release of free drug that exhibited $93.62 \pm 1.41 \%$ drug released after $4 \mathrm{~h}$. These results showed that proniosomal formulations could successfully sustain the in vitro release of Curcumin because they act as a drug reservoirs [42]. Besides, the higher in vitro release profile of free Curcumin demonstrates that its in vitro release was not hampered by the semipermeable membrane and the sink condition was successfully attained [40].
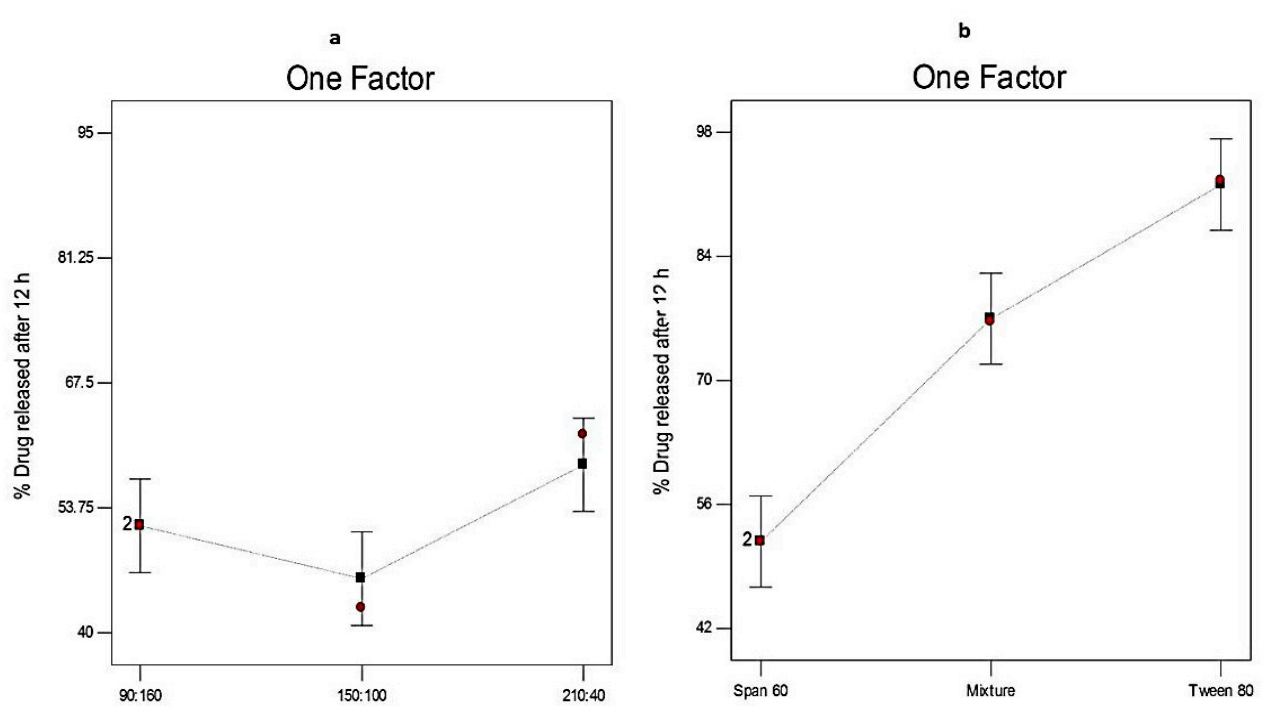

Figure 4. The in vitro release profile of Curcumin-loaded proniosomes and Curcumin dispersion for $12 \mathrm{~h}$. (a) ratio of surfactant to cholesterol (CHOL) and (b) type of surfactant. 
Figure 5 illustrates the influence of different independent variables on $\mathrm{Q}_{12 \mathrm{~h}}(\mathrm{Y} 2)$. ANOVA results (Table 4) investigates that the surfactant to CHOL ratio has significant influence $(p<0.05)$ on $\mathrm{Q}_{12 \mathrm{~h}}$. That might be due to that the in vitro release from the niosomal vesicles is dominated by the rigidity of the lipid membrane. Hence, as the concentration of CHOL increases, drug efflux decreases due to its membrane-stabilizing ability by filling the pores in the vesicular bilayer resulting in sustained drug release. However, a further increase in the concentration of $\mathrm{CHOL}$ reduces the leakage of the encapsulated drug by decreasing the membrane fluidity [45]. These results agreed with Shehata et al. [57] who reported that the gel-to-liquid phase transition of the vesicular membrane of proniosomes was abolished by increasing the concentration of $\mathrm{CHOL}$ resulting in the formation of more rigid vesicles and decreasing the drug release. However, a further increase of the $\mathrm{CHOL}$ concentration leads to disrupting the regular bilayer structure and increasing the efflux of the entrapped drug.
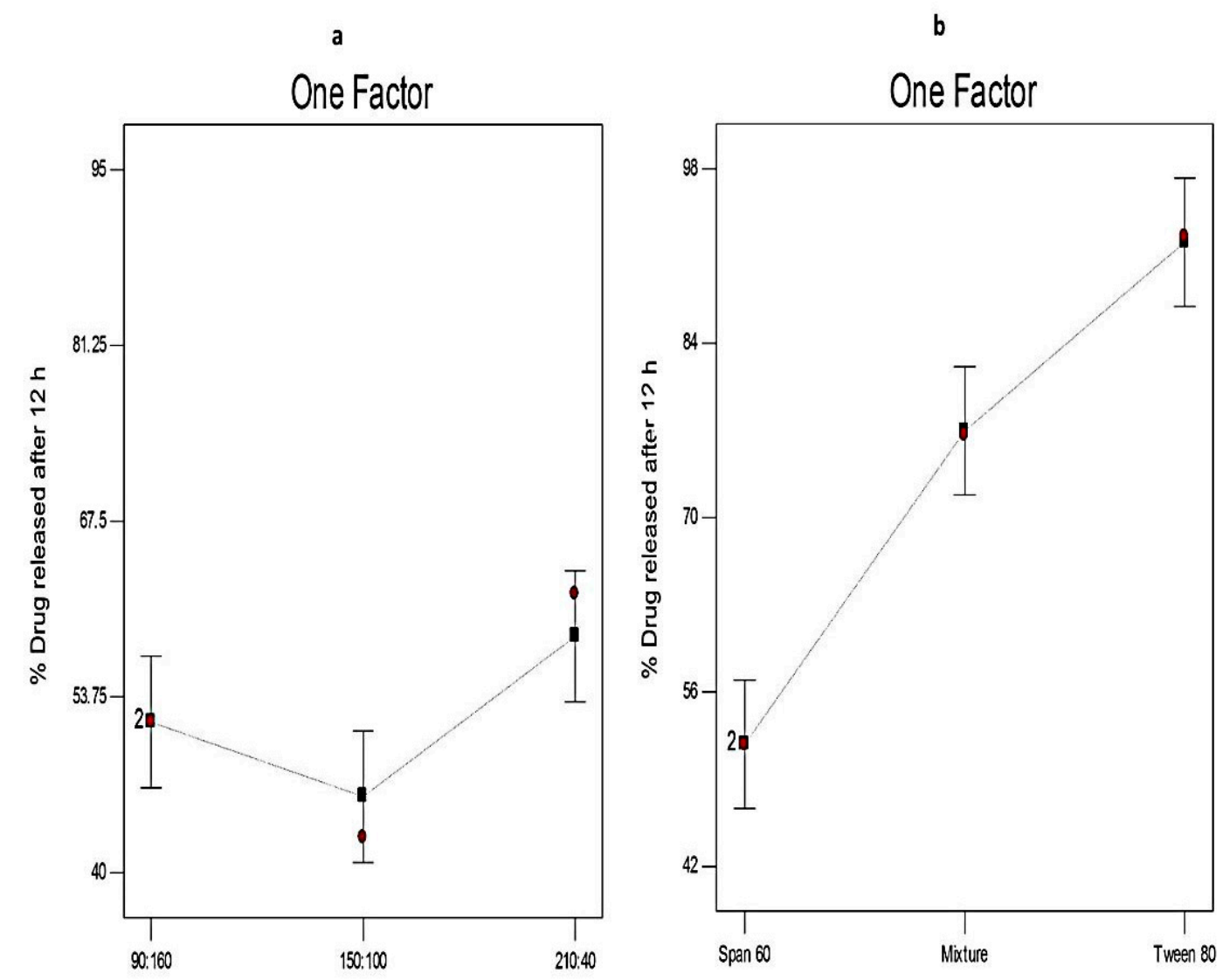

Figure 5. The effect of different independent variables (a) ratio of surfactant to CHOL and (b) type of surfactant on $\mathrm{Q}_{12 \mathrm{~h}}$ of Curcumin-loaded proniosomes according to $3^{2}$ factorial design. Abbreviation: $\mathrm{Q}_{12 \mathrm{~h}}, \%$ drug released after $12 \mathrm{~h}$.

With respect to the type of surfactant, it is clear that X2 has a significant effect $(p<0.01)$ on $\mathrm{Q}_{12 \mathrm{~h}}$ of Curcumin-loaded proniosomes. $\mathrm{Q}_{12 \mathrm{~h}}$ in the case of Tween 80-based proniosomes was significantly higher than that from Span 60-based proniosomes. That could be explained on the basis of the higher solubilizing power of Tween 80 on hydrophobic solutes (HLB = 15) compared to Span 60 [17]. These findings are in accordance with Sambhakar et al. [42] who investigated that the in vitro release of risperidone from Span-based proniosomes was lower than that from Tween-based vesicles due to the hydrophilicity of Tweens.

According to the correlation coefficient values $\left(R^{2}\right)$, it is clear that the in vitro release profile of both Curcumin-loaded proniosomes and Curcumin dispersion followed the Higuchi model (Table 5). This kinetic pattern showed that the release of Curcumin-loaded proniosomes is dominated by the 
diffusion model that depends on the concentration gradient of drug between the nanovesicles and dissolution medium [68].

Table 5. The calculated correlation coefficients for the in vitro release of Curcumin and Curcumin-loaded proniosomes employing different kinetic orders.

\begin{tabular}{cccccc}
\hline Formula & Zero Order & First Order & Higuchi Model & Hixson Crowell & Korsmeyer-Pappas \\
\hline F1 & 0.9890 & -0.9958 & 0.9991 & 0.9940 & 0.9988 \\
F2 & 0.9887 & -0.9948 & 0.9978 & 0.9958 & 0.9924 \\
F3 & 0.9902 & -0.9839 & 0.9997 & 0.9964 & 0.9889 \\
F4 & 0.9852 & -0.9913 & 0.9957 & 0.9896 & 0.9952 \\
F5 & 0.9854 & -0.9952 & 0.9966 & 0.9939 & 0.9949 \\
F6 & 0.9927 & -0.9846 & 0.9993 & 0.9955 & 0.9860 \\
F7 & 0.9842 & -0.9948 & 0.9966 & 0.9925 & 0.9960 \\
F8 & 0.9928 & -0.9959 & 0.9998 & 0.9992 & 0.9948 \\
F9 & 0.9931 & -0.9663 & 0.9990 & 0.9890 & 0.9801 \\
Curcumin & 0.9903 & -0.9897 & 0.9989 & 0.9982 & 0.9927 \\
\hline
\end{tabular}

\subsubsection{The Optimization of Curcumin-Loaded Proniosomes}

The optimization of Curcumin-loaded proniosomes was conducted by numerical analysis using Design-Expert software on the basis of achieving maximum EE\% and maximum \%drug released [69]. The selection of the optimized proniosomal formula was based on the desirability criteria.

The response variables could describe the performance of pharmaceutical formulations. In the desirability criteria, the choice of the optimized formula can be attained by the simultaneous optimization of these variables. Each response is converted into a desirability value and the total desirability value is calculated as the geometric mean of individual desirability values. The desirability value ranges from zero to one. Zero represents a completely undesirable response value and one describes a completely ideal or desirable response value. The desirability value increases as it gets closer to the target value [36,70].

F5 had the highest desirability index (0.650); hence, it was selected as the optimized formula. Moreover, the predicted values of $\% E E$ and $Q_{12}$ were 86.53 and $71.12 \%$, respectively. The calculated \% relative error was found to be less than 5 ( -3.94 and 0.32 for $\mathrm{Y} 1$ and $\mathrm{Y} 2$, respectively). These results indicated the fitness of this model in selecting the optimized formula (F5).

\subsection{Comparative Study of the Optimized Curcumin-Loaded Proniosomal Formula and the Conventional Niosomes}

\subsubsection{Determination of EE\%}

No significant difference in \%EE $(p>0.05)$ was observed between the optimized Curcumin-loaded proniosomal formula (F5) and the corresponding niosomes that have EE\% of $90.78 \pm 1.52 \%$.

\subsubsection{In Vitro Release Study}

Figure 6 investigates the in vitro release profiles of Curcumin from the optimized proniosomal formula (F5) and the corresponding niosomes. It was detected that the \% drug released from optimized Curcumin-loaded proniosomes was significantly $(p<0.01)$ higher than that from the conventional niosomes that demonstrated $61.42 \pm 1.71 \%$ cumulative drug released after $8 \mathrm{~h}$. Additionally, the similarity factor test showed that there is a significant difference between the in vitro release profiles of the two formulations because the $\mathrm{f}_{2}$ value was less than 50 (41). These findings may be explained on the basis of the adsorption of the lipid coat of Curcumin-loaded proniosomal vesicles on the hydrophilic carrier increasing its effective surface area [28]. Besides, it might be attributed to improving the solubility of Curcumin and changing its crystalline structure to the amorphous state after incorporation into the proniosomal vesicles [38]. Besides, Akhilesh et al. [71] reported that the in vitro release profile 
of proniosome-derived niosomes is superior to the corresponding niosomes due to their better size distribution. These results are also in a good agreement with Khudair et al. [72] who found that $\%$ Letrozole released from proniosomal formulations was higher than that from the conventional niosomes after $24 \mathrm{~h}$.

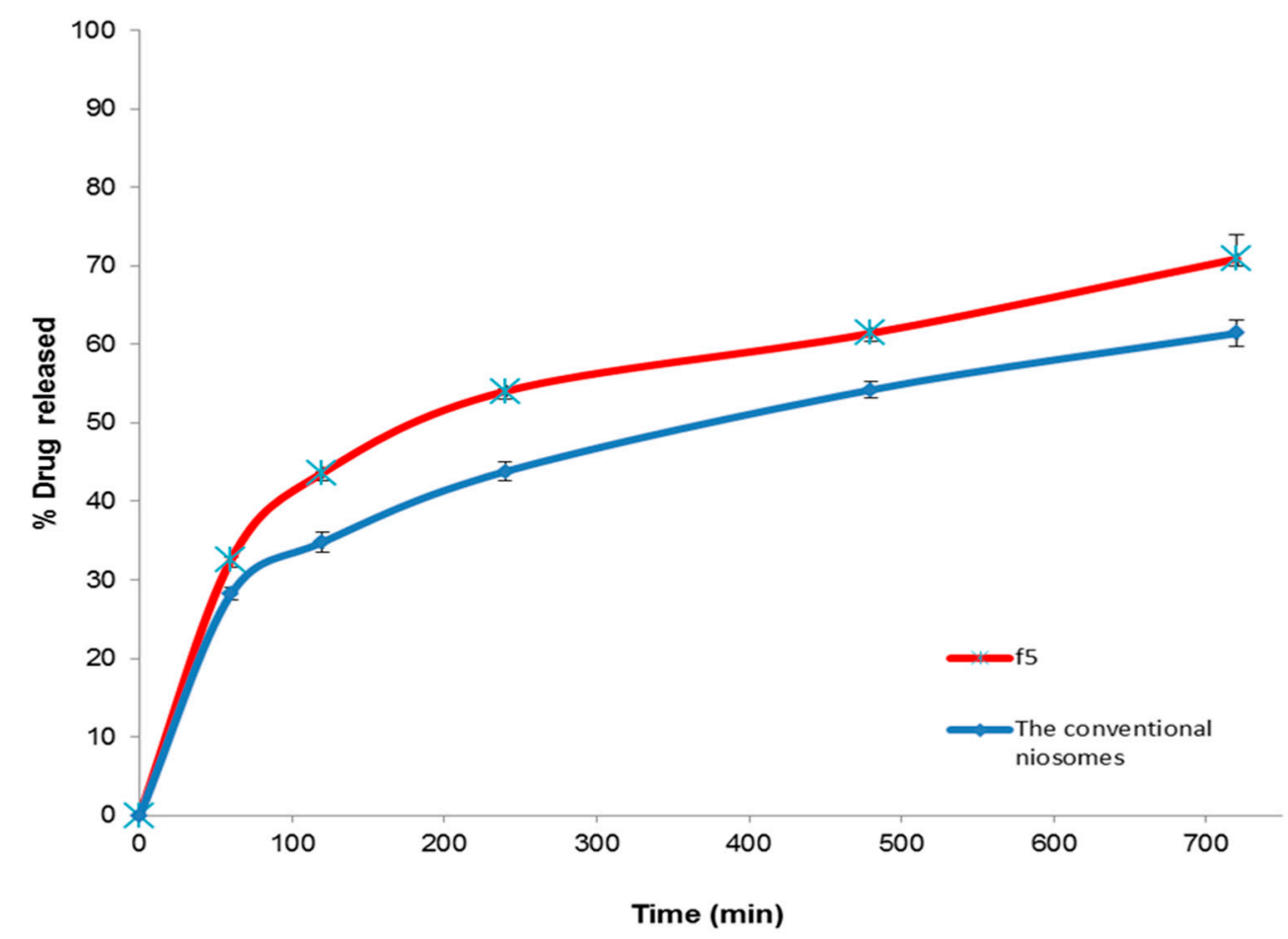

Figure 6. The in vitro release profile of the optimized Curcumin-loaded proniosomal formula and the conventional niosomes.

\subsubsection{The Stability Study}

The stability study, after storage of both F5 and the conventional niosomes for three months at $4-8{ }^{\circ} \mathrm{C}$, explored that there was a non-significant difference $(p>0.05)$ in the drug content, $E E \%$ and $\mathrm{Q}_{12 \mathrm{~h}}$ of the stored Curcumin proniosomal formula (F5) when compared with the fresh proniosomal formula (Table 6). Conversely, there was a significant decrease in the drug content $(p<0.05), \operatorname{EE} \%(p<0.01)$ and $\mathrm{Q}_{12 \mathrm{~h}}(p<0.05)$ of the stored niosomal dispersion when compared to the fresh one. These outcomes illustrated that proniosomes are a stable drug delivery system that can solve the storage problems related to conventional niosomes. That could be attributed to formulating proniosomes as a dry powder which is more stable than the aqueous niosomal dispersion during storage.

Table 6. Effect of storage on the properties of the optimized proniosomal formula and the corresponding niosomal formula.

\begin{tabular}{|c|c|c|c|c|}
\hline \multirow{2}{*}{ Parameter } & \multicolumn{2}{|c|}{ Proniosomal Formula } & \multicolumn{2}{|c|}{ Niosomal Formula } \\
\hline & Fresh & Stored & Fresh & Stored \\
\hline Drug Content (\%) & $97.44 \pm 1.69$ & $96.95 \pm 1.32$ & $95.94 \pm 1.27$ & $90.22 \pm 1.44$ \\
\hline EE $(\%)$ & $89.94 \pm 2.31$ & $87.86 \pm 1.82$ & $90.78 \pm 1.52$ & $83.02 \pm 2.11$ \\
\hline $\mathrm{Q}_{12 \mathrm{~h}}(\%)$ & $70.89 \pm 1.62$ & $68.94 \pm 0.90$ & $61.42 \pm 1.71$ & $53.12 \pm 0.97$ \\
\hline
\end{tabular}

Notes: Each value is presented as mean $\pm \mathrm{SD}(\mathrm{n}=3)$, the optimized Curcumin-loaded proniosomes is F5. Abbreviations: EE, entrapment efficiency; $\mathrm{Q}_{12 \mathrm{~h}} \%$ drug released after $12 \mathrm{~h}$. 
The above findings agreed with Bhama and Sambath [73] who concluded that proniosomes provide a stable drug delivery system that could minimize the stability pitfalls associated with conventional niosomes during storage.

\subsection{Characterization of the Optimized Curcumin-Loaded Proniosomes}

The optimized Curcumin-loaded proniosomal formula (F5) was characterized with respect to its morphological properties, vesicle size, zeta potential, and micromeritic properties. Additionally, the interaction of Curcumin with different excipients and changing the crystalline structure of Curcumin within proniosomes were investigated by Fourier transform infrared spectroscopy (FTIR) [38,74-78] (Figure S1) and Differential scanning calorimetry (DSC) study [38,79-85] (Figure S2) (Supplementary information).

\subsubsection{Morphological Characterization by SEM}

Figure 7 shows the SEM micrograph of the reconstituted Curcumin-loaded proniosomes (F5) as discrete and spherical nanovesicles with sharp boundaries. The spherical shape of Curcumin-loaded niosomal vesicles may be explained on the basis of the amphoteric nature of Span 60 and Tween 80 [86] that results in the development of closed bilayer niosomal vesicles in the aqueous medium and the tendency to reduce their surface free energy forming spherical vesicles [38,87].

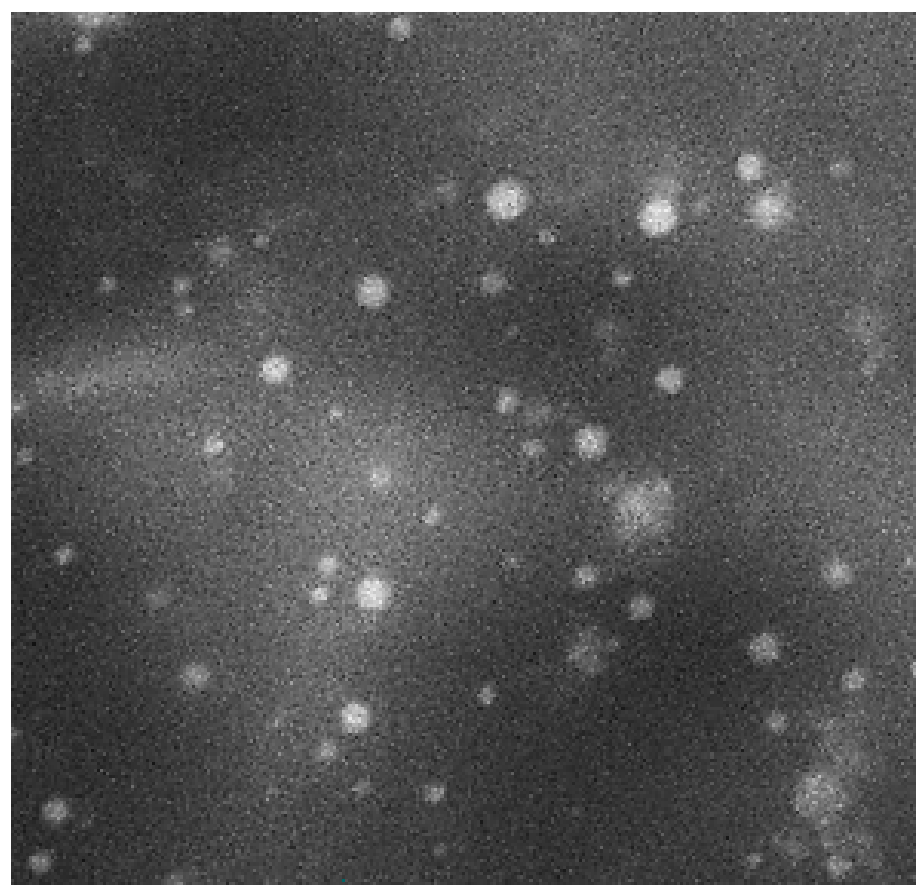

Figure 7. Scanning electron micrograph of the optimized Curcumin-loaded proniosomal formula (F5) after reconstitution.

\subsubsection{Determination of Vesicle Size and Zeta Potential}

Figure 8 investigated the symmetric unimodal frequency distribution pattern of the optimized Curcumin-loaded proniosomal formula (F5). The vesicle size of the reconstituted proniosomal formula was $251.2 \mathrm{~nm}$ with a low polydispersity index (PDI) value of 0.355 . A PDI value of 1 indicates a wide variation in particle size; a reported PDI value of 0 investigates the absence of the size variation [45]. The obtained small value of PDI of the reconstituted proniosomes demonstrates homogenous distribution and limited variation of the vesicle size. 


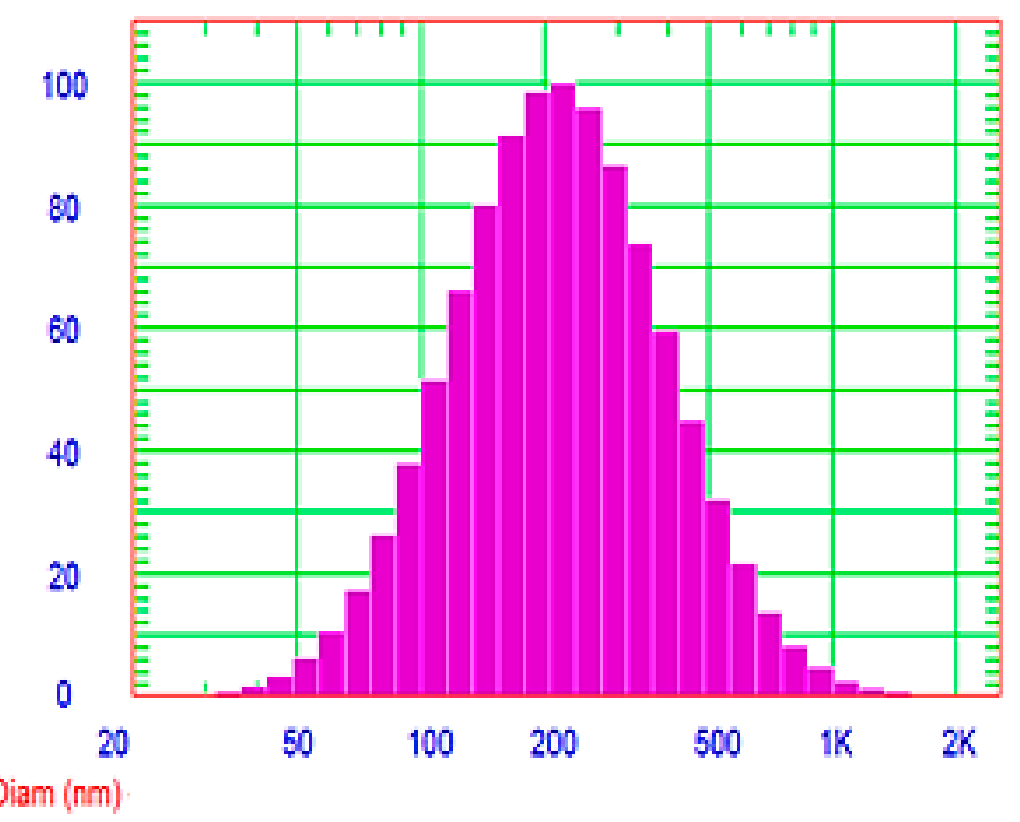

Figure 8. Particle size distribution curve of the optimized Curcumin-loaded proniosomal formula (F5) after reconstitution.

Zeta potential describes the net charge of the colloidal dispersions (Figure 9). Large zeta potential value of F5 $(-35.27 \mathrm{mv})$ investigates the stability of the reconstituted proniosomal dispersion due to repulsion between different niosomal vesicles as a result of the formation of a high-energy barrier between the nanovesicles that results in increasing the stability of the niosomal dispersion and preventing their agglomeration [28].

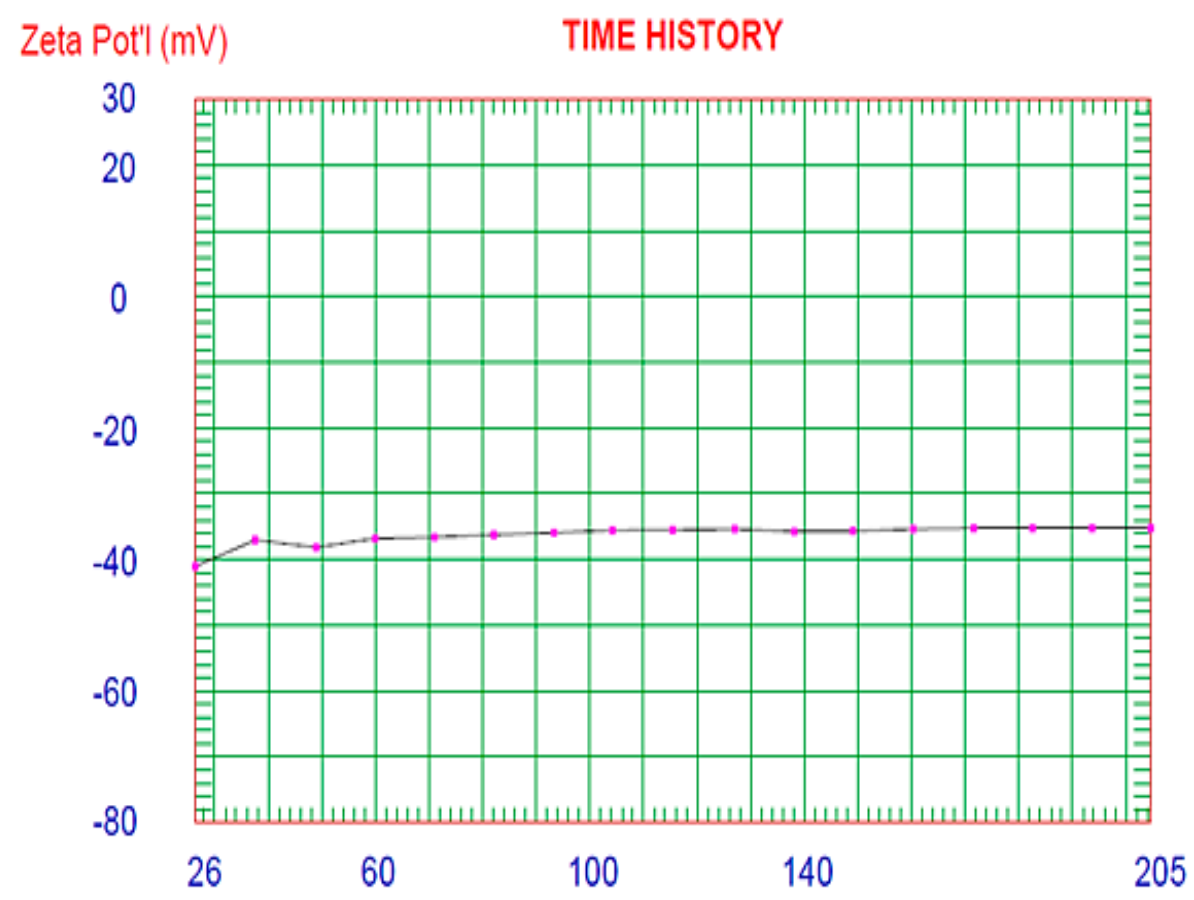

Figure 9. Zeta potential distribution of the optimized Curcumin-loaded proniosomal formula (F5).

The negative zeta potential of nanovesicles, containing non-ionic surfactants, were explained by many researchers [36]. Caracciolo et al. [88] demonstrated that Tween 20-based niosomal vesicles have a negative zeta potential due to the orientation of hydroxyl groups of both Tween 20 and cholesterol 
with respect to water and the consequent redirection of the ionic charges in the aqueous medium. Junyaprasert et al. [89] explained the negative charge of the drug-free niosomes, containing Span 60, on the basis of the adsorption of counterions at the surface of nanovesicle. Furthermore, Pawar et al. [50] demonstrated that the ionization of free groups present on the vesicular surface could be the cause of the negative charge of Span 60-based Bifonazole niosomes. Essa et al. [90] reported that niosomes containing Span 40 have a negative zeta potential due to the preferential adsorption of hydroxyl ions on the vesicular surface.

The reasonable cellular uptake of the negatively charged nanovesicles, without repulsion with the negatively charged cell membrane, could be explained on the basis of the non-specific adsorption of nanovesicles on the cellular membrane, and consequent development of clusters of these nanoparticles [91].

\subsubsection{Determination of the Micromeritic Properties}

Good flowability of powders has a critical role during the development of solid dosage forms. Flowability is assessed by the angle of repose $(\theta)$ which is the angle between the surface of the powder heap and the horizontal surface [92]. Studying the micromeritic properties, using the funnel method, showed that the angle of repose of Curcumin-loaded proniosomal powder $\left(28.26^{\circ} \pm 0.25^{\circ}\right)$ was lower than that of maltodextrin $\left(46.24^{\circ} \pm 0.33^{\circ}\right)$. Hence, the flowability of the optimized proniosomal powder (F5) was higher than that of maltodextrin powder.

A value of $\theta<30^{\circ}$ describes excellent powder flowability, whereas $\theta>56^{\circ}$ describes very poor flowability. The intermediate range designates good flowability ( $\theta$ between $31-35^{\circ}$ ), fair flowability ( $\theta$ between $36-40^{\circ}$ ), passable flowability $\left(\theta\right.$ between $41-45^{\circ}$ ), and poor flowability $(\theta$ between 46-55 ${ }^{\circ}$ ) [38]. Accordingly, the flowability of F5 was rated as excellent flowability, while pure maltodextrin powder has poor flowability.

These results are compatible with other studies $[60,93]$ that investigated that proniosomes are non-sticky provesicular powders that have higher flowability than the carriers. Improving the flowability of proniosomal powder compared to the pure carrier could be attributable to the coating of the surfactant film on the carrier surface and reducing the cohesive interactions between carrier particles [60].

\subsection{Evaluation of the Antiviral Activity and Cytotoxicity}

The antiviral activity of Curcumin was demonstrated by the molecular docking study to demonstrate the ability of Curcumin to bind effectively with the active site of DNA polymerase of HSV-1 [16,94-102] (Figure S3) (Supplementary information). The antiviral activity of the reconstituted Curcumin-loaded proniosomal formula (F5) were tested and compared with that of Curcumin dispersion. The antiviral activity was studied using an improved plaque-reduction assay [49] against the HS-1 virus that was grown on Vero cells, Figure 10. This technique allows the development of HS-1 plaques without the use of thickening agents. In other techniques, the addition of thickener could cause a number of technical problems such as toxicity of the thickener to virus or host cells and interference with the tested antiviral agents [49].

The results revealed that both F5 and Curcumin were able to reduce the viral plaques by $90 \pm 1.60 \%$ and $75 \pm 0.82 \%$, respectively at a concentration of $30 \mu \mathrm{M}$. Other researchers such as Flores et al. [2] have also reported that $30 \mu \mathrm{M}$ Curcumin possesses the ability to serve as a therapeutic agent that minimizes the transmission of HS viruses.

It is obvious that the antiviral activity of the reconstituted proniosomal Curcumin (F5) was significantly $(p<0.001)$ higher than that of the corresponding Curcumin dispersion. The higher antiviral activity could be attributable to the interaction of the reconstituted proniosomal vesicles with viral cells by endocytosis or fusion $[103,104]$. The adsorption and fusion of the formed niosomal vesicles onto the membrane surface results in a high thermodynamic activity gradient of Curcumin at the interface, which is considered to be the main driving force for the permeation of lipophilic species [105]. 
Additionally, proniosomes can increase the permeability of Curcumin due to the penetration enhancing effect of surfactants [106]. Therefore, the proniosomal formulation could be a promising drug delivery system that could improve the antiviral activity of Curcumin. These outcomes are in agreement with Monavari et al. [104] who reported that ACV-loaded niosomes were more efficient than the free ACV as antiviral agent, because ACV-loaded niosomes showed nearly 3-fold improvement in the antiviral activity against HSV-1 than the free drug.

a

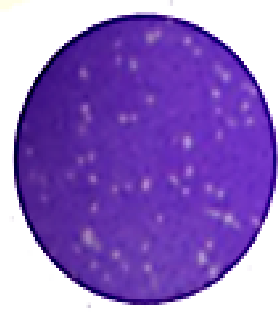

b

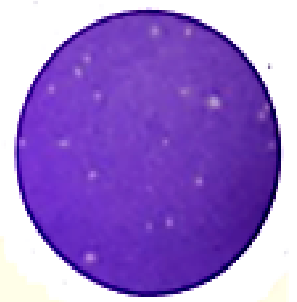

c

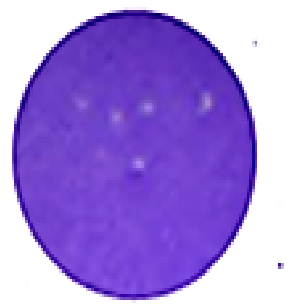

d

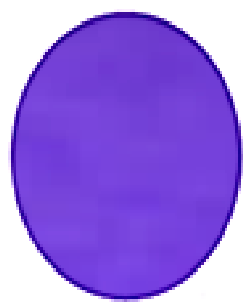

Figure 10. Plaque formation of Herpes simplex type 1 virus (HSV-1) for (a) untreated group, (b) Curcumin group, (c) F5 group, and (d) Curcumin and ACV group, $(\mathrm{n}=3)$. Abbreviation: F5, the optimized Curcumin-loaded proniosomal formula; ACV, Acyclovir; HS-1, Herpes simplex type 1 virus.

Determination of the cytotoxicity of an antiviral drug is a critical issue to ensure host safety because it should not exhibit acute or long-term host toxicity [107]. The ideal antiviral drug should have antiviral activity at very low concentrations and be cytotoxic only at very high concentrations, thus yielding high selectivity [108]. The cytotoxicity was described by the half-maximal cytotoxic concentration $\left(\mathrm{CC}_{50}\right)$. The $\mathrm{CC}_{50}$ of $\mathrm{F5}(200 \mu \mathrm{M})$ was significantly $(p<0.01$ and $p<0.001)$ higher than that of Curcumin $(160 \mu \mathrm{M})$ and ACV $(80 \mu \mathrm{M})$, respectively (Figure 11). These findings explored the greater safety of F5 that exhibits cytotoxicity at higher concentrations than both Curcumin and ACV.

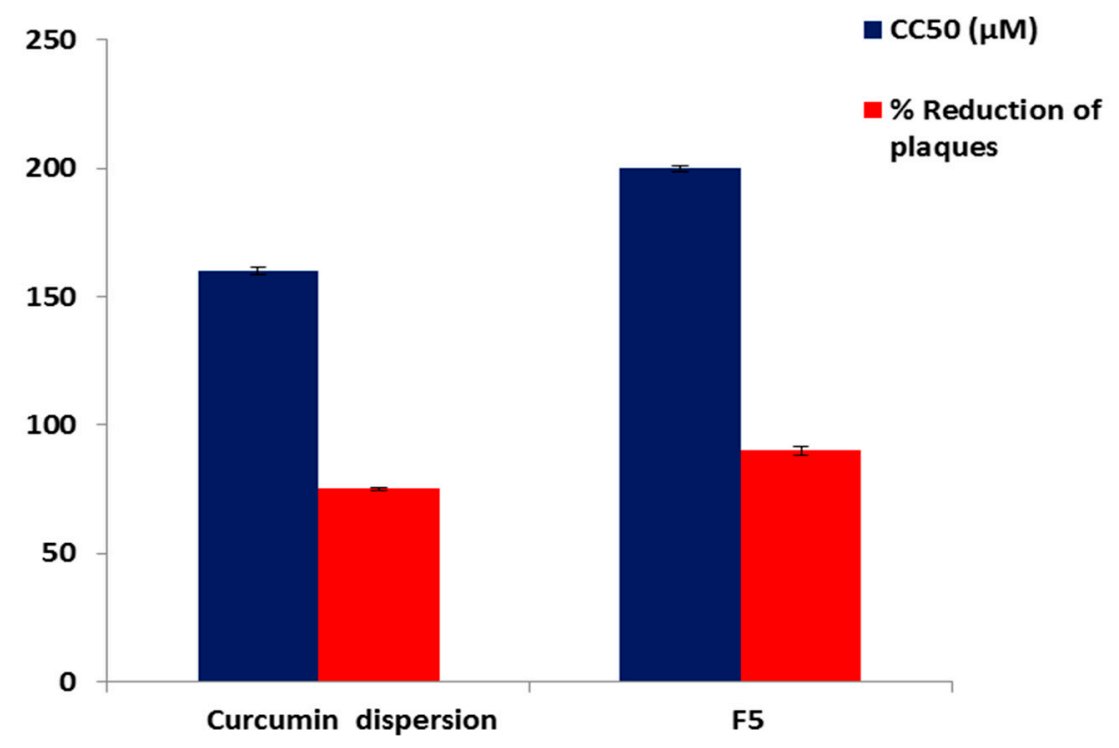

Figure 11. \% Reduction of plaques and $\mathrm{CC}_{50}$ of Curcumin dispersion and F5 against HS-I virus. Each point represents the mean $\pm \mathrm{SD}(\mathrm{n}=3)$. Abbreviation: F5, the optimized Curcumin-loaded proniosomal formula; HS-I, Herpes simplex type I virus; $\mathrm{CC}_{50}$, the half-maximal cytotoxic concentration. 
SI denotes the selectivity of the antiviral. SI was calculated by dividing $\mathrm{CC}_{50}$ as a measure of cytotoxicity on IC50 (50\% inhibitory concentration) as a measure of inhibitory potential [109]. Interestingly, the SI value of F5 (12.5) was significantly higher $(p<0.01)$ than Curcumin dispersion (8), indicating the higher selectivity of F5.

These findings are in accordance with Anggakusuma et al. [110] who found that Curcumin nanoformulation improved the antiviral activity against the hepatitis $C$ virus without any toxic effect.

Moreover, the Curcumin-loaded proniosomal formula (F5) was further tested for its combined effects with ACV on the anti-HSV-1 activity. F5 $(30 \mu \mathrm{M})$ proved to increase the $\mathrm{CC}_{50}$ of ACV to $200 \mu \mathrm{M}$ and reduce its effective dose that produced $100 \pm 1.35 \%$ reduction of viral plaques from $12.2 \mu \mathrm{M}$ to $6.25 \mu \mathrm{M}$ (Figure 12). Moreover, F5 increased the SI value of ACV from 13.1 to 64.5. Accordingly, the safety and selectivity of ACV improved after the addition of F5. These findings showed the positive impact of adding the proniosomal Curcumin to ACV forming a potent and less toxic mixture.

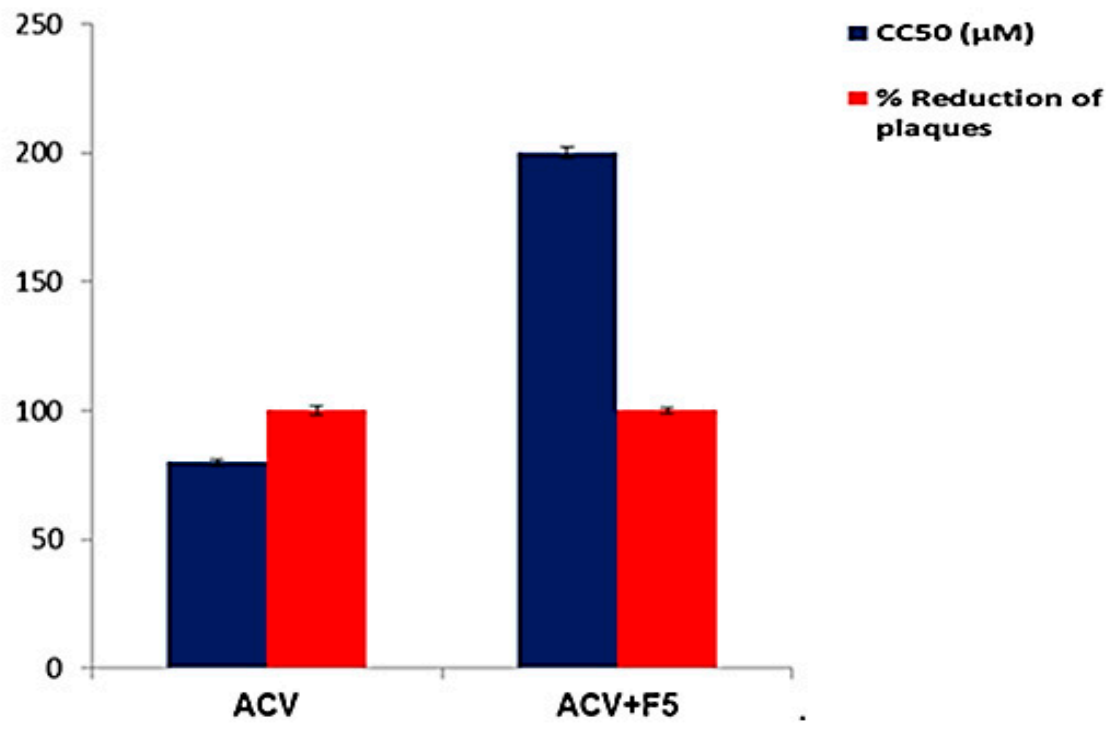

Figure 12. \% Reduction of plaques and $\mathrm{CC}_{50}$ of acyclovir (ACV) before and after addition of F5 against HS-1 virus, each point represents the mean \pm SD $(n=3)$. Abbreviation: F5, the optimized Curcumin-loaded proniosomal formula; ACV, Acyclovir; HS-1, Herpes simplex type I virus; $\mathrm{CC}_{50}$, the half-maximal cytotoxic concentration.

According to the previous results, it is worth noting that the dry proniosomes are free-flowing powders that offer a more convenient method for preparing niosomes than other conventional techniques. Moreover, the in vitro release profile and stability of proniosomes are superior to the corresponding niosomes. Additionally, proniosomes of Curcumin have higher antiviral activity and safety than that of the corresponding Curcumin dispersion. Therefore, proniosomes are a promising drug delivery system for Curcumin.

\section{Conclusions}

The present study investigated the formulation of Curcumin-loaded provesicular nanocarriers as an effective antiviral agent. Nine Curcumin-loaded proniosomes were effectively prepared using the slurry method according to $3^{2}$ factorial design. The optimized proniosomal formulation (F5) was selected on the basis of maximizing both $\mathrm{EE} \%$ and $\mathrm{Q}_{12 \mathrm{~h}}$ according to the desirability criteria. F5 exhibited a prolonged release profile and relatively high $\mathrm{EE} \%$. Upon comparing with the corresponding niosomal formula, the optimized proniosomal formula demonstrated higher stability and a significant increase in $Q_{12 h}$. F5 exhibited a significant increase in both the antiviral activity and safety compared to pure Curcumin. Besides, the antiviral activity and safety of ACV improved after the addition of F5. 
In summary, these findings showed that Curcumin-loaded proniosomes are a promising and stable nanodelivery system that could overcome the pitfalls of the corresponding niosomes and improve both the antiviral activity and safety of Curcumin.

Supplementary Materials: The following are available online, Figure S1: FTIR spectrum of (a) Curcumin, (b) Tween 80, (c) Span 60, (d) maltodextrin, (e) CHOL, (f) plain proniosomes and (g) the optimized Curcumin proniosomal formula, Figure S2: DSC thermogram of (a) Curcumin, (b) Tween 80, (c) Span 60, (d) maltodextrin, (e) CHOL, (f) plain proniosomes and (g) the optimized Curcumin proniosomal formula, and Figure S3: (A) 3D presentation of DNA polymerase/Curcumin complex (B) Curcumin (Red) docked in the active site of DNA polymerase, (C) 2D presentation showing interaction of Curcumin with the active site.

Author Contributions: Conceptualization, F.A.B. and E.A.M.; methodology, E.A.M. and F.A.B.; software, E.A.M. and A.A.E.; validation, F.A.B. and E.A.M.; formal analysis, E.A.M. and A.A.E.; investigation, E.A.M., A.E.A., and A.H.H.; resources, F.A.B. and E.A.M.; data curation, E.A.M., A.E.A., and A.H.H. writing-original draft preparation, E.A.M. and F.A.B.; writing-review and editing, F.A.B., E.A.M., and A.A.E.; visualization, F.A.B. and E.A.M.; supervision, F.A.B. and E.A.M. All authors have read and agreed to the published version of the manuscript.

Funding: This research received no external funding.

Conflicts of Interest: The authors declare no conflict of interest.

\section{References}

1. Marchi, S.; Trombetta, C.M.; Gasparini, R.; Temperton, N.; Montomoli, E. Epidemiology of herpes simplex virus type 1 and 2 in Italy: A seroprevalence study from 2000 to 2014. J. Prev. Med. Hyg. 2017, 58, E27.

2. Flores, D.J.; Lee, L.H.; Adams, S.D. Inhibition of curcumin-treated Herpes Simplex virus 1 and 2 in vero cells. Adv. Microbiol. 2016, 6, 276-287. [CrossRef]

3. Barton, S.; Celum, C.; Shacker, T. The role of anti-HSV therapeutics in the HIV-infected host and in controlling the HIV epidemic. Herpes J. IHMF 2005, 12, 15-22.

4. Bag, P.; Chattopadhyay, D.; Mukherjee, H.; Ojha, D.; Mandal, N.; Sarkar, M.C.; Chatterjee, T.; Das, G.; Chakraborti, S. Anti-herpes virus activities of bioactive fraction and isolated pure constituent of Mallotus peltatus: An ethnomedicine from Andaman Islands. Virol. J. 2012, 9, 1-12. [CrossRef] [PubMed]

5. Chattopadhyay, D.; Khan, M.T.H. Ethnomedicines and ethnomedicinal phytophores against herpesviruses. Biotechnol. Annu. Rev. 2008, 14, 297-348. [PubMed]

6. Gupta, S.C.; Patchva, S.; Aggarwal, B.B. Therapeutic roles of curcumin: Lessons learned from clinical trials. AAPS J. 2013, 15, 195-218. [CrossRef] [PubMed]

7. Aggarwal, B.B.; Yuan, W.; Li, S.; Gupta, S.C. Curcumin-free turmeric exhibits anti-inflammatory and anticancer activities: Identification of novel components of turmeric. Mol. Nutr. Food Res. 2013, 57, 1529-1542. [CrossRef]

8. Bhawana, B.R.; Buttar, H.S.; Jain, V.; Jain, N. Curcumin nanoparticles: Preparation, characterization, and antimicrobial study. J. Agric. Food Chem. 2011, 59, 2056-2061. [CrossRef]

9. El-Mahdy, M.M.; Hassan, A.S.; El-Badry, M.; El-Gindy, G.E.-D.A. Performance of Curcumin in Nanosized Carriers Niosomes and Ethosomes as Potential Anti-Inflammatory Delivery System for Topical Application. Bull. Pharm. Sci. Assiut. 2020, 43, 105-122. [CrossRef]

10. Xu, Y.-Q.; Chen, W.-R.; Tsosie, J.K.; Xie, X.; Li, P.; Wan, J.-B.; He, C.-W.; Chen, M.-W. Niosome encapsulation of curcumin: Characterization and cytotoxic effect on ovarian cancer cells. J. Nanomater. 2016, 2016, 1-9. [CrossRef]

11. Kutluay, S.B.; Doroghazi, J.; Roemer, M.E.; Triezenberg, S.J. Curcumin inhibits herpes simplex virus immediate-early gene expression by a mechanism independent of p300/CBP histone acetyltransferase activity. Virology 2008, 373, 239-247. [CrossRef] [PubMed]

12. Joe, B.; Vijaykumar, M.; Lokesh, B. Biological properties of curcumin-cellular and molecular mechanisms of action. Crit. Rev. Food Sci. Nutr. 2004, 44, 97-111. [CrossRef] [PubMed]

13. Mathew, D.; Hsu, W.-L. Antiviral potential of curcumin. J. Funct. Foods 2018, 40, 692-699. [CrossRef]

14. Manoharan, Y.; Haridas, V.; Vasanthakumar, K.; Muthu, S.; Thavoorullah, F.F.; Shetty, P. Curcumin: A Wonder Drug as a Preventive Measure for COVID19 Management. Indian J. Clin. Biochem. 2020, 35, 373-375. [CrossRef] 
15. Qin, Y.; Lin, L.; Chen, Y.; Wu, S.; Si, X.; Wu, H.; Zhai, X.; Wang, Y.; Tong, L.; Pan, B. Curcumin inhibits the replication of enterovirus 71 in vitro. Acta Pharm. Sin. B 2014, 4, 284-294. [CrossRef]

16. El-Halim, S.M.A.; Mamdouh, M.A.; El-Haddad, A.E.; Soliman, S.M. Fabrication of Anti-HSV-1 Curcumin Stabilized Nanostructured Proniosomal Gel: Molecular Docking Studies on Thymidine Kinase Proteins. Sci. Pharm. 2020, 88, 9. [CrossRef]

17. Abdelbary, G.A.; Amin, M.M.; Zakaria, M.Y. Ocular ketoconazole-loaded proniosomal gels: Formulation, ex vivo corneal permeation and in vivo studies. Drug Deliv. 2017, 24, 309-319. [CrossRef]

18. Lembo, D.; Cavalli, R. Nanoparticulate delivery systems for antiviral drugs. Antivir. Chem. Chemother. 2010, 21, 53-70. [CrossRef]

19. Sharma Vijay, K.; Mishra, D.; Sharma, A.; Srivastava, B. Liposomes: Present prospective and future challenges. Int. J. Curr. Pharm. Rev. Res. 2010, 1, 6-16.

20. Muzzalupo, R.; Tavano, L. Niosomal drug delivery for transdermal targeting: Recent advances. Res. Rep. Transdermal. Drug Deliv. 2015, 4, 23-33. [CrossRef]

21. Radha, G.; Rani, T.S.; Sarvani, B. A review on proniosomal drug delivery system for targeted drug action. J. Basic Clin. Pharm. 2013, 4, 42. [CrossRef]

22. Kumar, K.; Rai, A. Proniosomal formulation of curcumin having anti-inflammatory and anti-arthritic activity in different experimental animal models. Die Pharm. Int. J. Pharm. Sci. 2012, 67, 852-857.

23. Dubey, A.; Prabhu, P. Development and evaluation of lornoxicam loaded maltodextrin based proniosomes. Development 2013, 5, 865-872.

24. Khatoon, M.; Shah, K.U.; Din, F.U.; Shah, S.U.; Rehman, A.U.; Dilawar, N.; Khan, A.N. Proniosomes derived niosomes: Recent advancements in drug delivery and targeting. Drug Deliv. 2017, 24, 56-69. [CrossRef]

25. Peele, K.A.; Chandrasai, P.; Srihansa, T.; Krupanidhi, S.; Sai, A.V.; Babu, D.J.; Indira, M.; Reddy, A.R.; Venkateswarulu, T. Molecular docking and dynamic simulations for antiviral compounds against SARS-CoV-2: A computational study. Inform. Med. Unlocked 2020, 100345. [CrossRef]

26. Shivanika, C.; Kumar, D.; Ragunathan, V.; Tiwari, P.; Sumitha, A. Molecular docking, validation, dynamics simulations, and pharmacokinetic prediction of natural compounds against the SARS-CoV-2 main-protease. J. Biomol. Struct. Dyn. 2020, 3, 1-27.

27. Dar, A.M.; Mir, S. Molecular docking: Approaches, types, applications and basic challenges. J. Anal. Bioanal. Tech. 2017, 8, 1-3. [CrossRef]

28. Sengodan, T.; Sunil, B.; Vaishali, R.; Chandra, R.J.; Nagar, S.; Nagar, O. Formulation and evaluation of maltodextrin based proniosomes loaded with indomethacin. Int. J. Pharmtech Res. 2009, 1, 517-523.

29. Boddu, M.; Choppari, V.; Rapalli, V.K.; Badam, M. Formulation and Evaluation of Proniosomes of Felodipine. Drug Des. 2017, 6. [CrossRef]

30. Farghaly, D.A.; Aboelwafa, A.A.; Hamza, M.Y.; Mohamed, M.I. Topical delivery of fenoprofen calcium via elastic nano-vesicular spanlastics: Optimization using experimental design and in vivo evaluation. AAPS PharmSciTech 2017, 18, 2898-2909. [CrossRef]

31. El Gamal, S.S.; Naggar, V.F.; Allam, A.N. Optimization of acyclovir oral tablets based on gastroretention technology: Factorial design analysis and physicochemical characterization studies. Drug Dev. Ind. Pharm. 2011, 37, 855-867. [CrossRef]

32. Marwa, H.A.; Omaima, A.S.; Hanaa, A.E.-G.; Hanan, M.E.-N. Optimizing proniosomes for controlled release of ketoprofen using Box-Behnken experimental design. Int. J. Pharm. Sci. Res. 2011, 2, 2195.

33. Chauhan, M.K.; Sahoo, P.K.; Rawat, A.S.; Duggal, D.; Kandwal, M.; Sandal, N. Formulation, characterization and in vitro evaluation of tactically engineered proniosomes for successful oral delivery of ramipril. Der. Pharm. Lett. 2015, 7, 93-97.

34. Sammour, R.M.; Taher, M.; Chatterjee, B.; Shahiwala, A.; Mahmood, S. Optimization of Aceclofenac Proniosomes by Using Different Carriers, Part 1: Development and Characterization. Pharmaceutics 2019, 11, 350. [CrossRef] [PubMed]

35. El-Menshawe, S.F.; Ali, A.A.; Halawa, A.A.; El-Din, A.S.S. A novel transdermal nanoethosomal gel of betahistine dihydrochloride for weight gain control: In-vitro and in-vivo characterization. Drug Des. Dev. Ther. 2017, 11, 3377. [CrossRef]

36. Badria, F.; A Fayed, H.; K Ibraheem, A.; Mazyed, E.A. Formulation of Sodium Valproate Nanospanlastics as a Promising Approach for Drug Repurposing in the Treatment of Androgenic Alopecia. Pharmaceutics 2020, 12, 866. [CrossRef] 
37. Sahu, A.K.; Mishra, J.; Mishra, A.K. Introducing Tween-curcumin niosomes: Preparation, characterization and microenvironment study. Soft Matter 2020, 16, 1779-1791. [CrossRef]

38. Mazyed, E.A.;Zakaria, S. Enhancement of dissolution characteristics of clopidogrel bisulphate by proniosomes. Int. J. Appl. Pharm. 2019, 11, 77-85. [CrossRef]

39. Abd-Elal, R.M.; Shamma, R.N.; Rashed, H.M.; Bendas, E.R. Trans-nasal zolmitriptan novasomes: In-Vitro preparation, optimization and in-vivo evaluation of brain targeting efficiency. Drug Deliv. 2016, 23, 3374-3386. [CrossRef]

40. Mazyed, E.A.; Abdelaziz, A.E. Fabrication of Transgelosomes for Enhancing the Ocular Delivery of Acetazolamide: Statistical Optimization, In Vitro Characterization, and In Vivo Study. Pharmaceutics 2020, 12, 465. [CrossRef]

41. Ammar, H.; Haider, M.; Ibrahim, M.; El Hoffy, N. In vitro and in vivo investigation for optimization of niosomal ability for sustainment and bioavailability enhancement of diltiazem after nasal administration. Drug Deliv. 2017, 24, 414-421. [CrossRef] [PubMed]

42. Sambhakar, S.; Paliwal, S.; Sharma, S.; Singh, B. Formulation of risperidone loaded proniosomes for effective transdermal delivery: An in-vitro and in-vivo study. Bull. Fac. Pharm. Cairo Univ. 2017, 55, 239-247. [CrossRef]

43. Moore, J.W.; Flanner, H.H. Mathematical comparison of curves with an emphasis on in Vitro Dissolution Profiles. Pharm. Technol. 1996, 20, 64-74.

44. Bansal, S.; Aggarwal, G.; Chandel, P.; Harikumar, S. Design and development of cefdinir niosomes for oral delivery. J. Pharm. Bioall. Sci. 2013, 5, 318.

45. Nasr, M. In vitro and in vivo evaluation of proniosomes containing celecoxib for oral administration. AAPS PharmSciTech 2010, 11, 85-89. [CrossRef] [PubMed]

46. Nyol, S.; Gupta, M.M. Immediate drug release dosage form: A review. J. Drug Deliv. Ther. 2013, 3, 1-10. [CrossRef]

47. Badria, F.A.; Abu-Karam, M.; Mikhaeil, B.R.; Maatooq, G.T.; Amer, M. Anti-herpes activity of isolated compounds from frankincense. Biosci. Biotechnol. Res. Asia 2016, 1, 1-10.

48. Henen, M.A.; El Bialy, S.A.; Goda, F.E.; Nasr, M.N.; Eisa, H.M. [1,2,4]Triazolo[4,3-a]quinoxaline: Synthesis, antiviral, and antimicrobial activities. Med. Chem. Res. 2012, 21, 2368-2378. [CrossRef]

49. Abou-Karam, M.; Shier, W.T. A simplified plaque reduction assay for antiviral agents from plants. Demonstration of frequent occurrence of antiviral activity in higher plants. J. Nat. Prod. 1990, 53, 340-344. [CrossRef] [PubMed]

50. Pawar, H.A.; Attarde, V.B.; Parag Subhash, G. Optimization of Bifonazole-Loaded Nisomal Formulation Using Plackett-Burman Design and 23 Factorial Design. Open Pharm. Sci. J. 2016, 3, 31-48. [CrossRef]

51. Ruckmani, K.; Sankar, V. Formulation and optimization of zidovudine niosomes. AAPS PharmSciTech 2010, 11, 1119-1127. [CrossRef] [PubMed]

52. Food, U.; Administration, D. Inactive Ingredient Search for Approved Drug Products; FDA Database: Silver Spring, MD, USA, 2017.

53. Food, U.; Administration, D. Gras Substances (Scogs) Database; FDA Database: Silver Spring, MD, USA, 2012.

54. Kumar, G.P.; Rajeshwarrao, P. Nonionic surfactant vesicular systems for effective drug delivery-An overview. Acta Pharm. Sin. B 2011, 1, 208-219. [CrossRef]

55. Bachhav, A.A. Proniosome: A novel non-ionic provesicules as potential drug carrier. Asian J. Pharm. 2016, 10,1-10. [CrossRef]

56. Blazek-Welsh, A.I.; Rhodes, D.G. Maltodextrin-based proniosomes. AAPS Pharmsci. 2001, 3, 1. [CrossRef]

57. Shehata, T.M.; Abdallah, M.H.; Ibrahim, M.M. Proniosomal oral tablets for controlled delivery and enhanced pharmacokinetic properties of acemetacin. AAPS PharmSciTech 2015, 16, 375-383. [CrossRef]

58. Verma, P.; Prajapati, S.K.; Yadav, R.; Senyschyn, D.; Shea, P.R.; Trevaskis, N.L. Single intravenous dose of novel Flurbiprofen-loaded Proniosome formulations provides prolonged systemic exposure and anti-inflammatory effect. Mol. Pharm. 2016, 13, 3688-3699. [CrossRef]

59. Hu, C.; Rhodes, D.G. Proniosomes: A novel drug carrier preparation. Int. J. Pharm. 1999, 185, $23-35$. [CrossRef]

60. Yuksel, N.; Bayindir, Z.S.; Aksakal, E.; Ozcelikay, A.T. In situ niosome forming maltodextrin proniosomes of candesartan cilexetil: In vitro and in vivo evaluations. Int. J. Biol. Macromol. 2016, 82, 453-463. [CrossRef] 
61. Naggar, V.F.; El Gamal, S.S.; Allam, A.N. Proniosomes as a stable carrier for oral acyclovir: Formulation and physicochemical characterization. J. Am. Sci. 2012, 8, 417-428.

62. Abd-Elbary, A.; El-Laithy, H.; Tadros, M. Sucrose stearate-based proniosome-derived niosomes for the nebulisable delivery of cromolyn sodium. Int. J. Pharm. 2008, 357, 189-198. [CrossRef] [PubMed]

63. Araujo, J.; Gonzalez-Mira, E.; Egea, M.; Garcia, M.; Souto, E. Optimization and physicochemical characterization of a triamcinolone acetonide-loaded NLC for ocular antiangiogenic applications. Int. J. Pharm. 2010, 393, 168-176. [CrossRef] [PubMed]

64. Al-Mahallawi, A.M.; Khowessah, O.M.; Shoukri, R.A. Enhanced non invasive trans-tympanic delivery of ciprofloxacin through encapsulation into nano-spanlastic vesicles: Fabrication, in-vitro characterization, and comparative ex-vivo permeation studies. Int. J. Pharm. 2017, 522, 157-164. [CrossRef]

65. El-Laithy, H.M.; Shoukry, O.; Mahran, L.G. Novel sugar esters proniosomes for transdermal delivery of vinpocetine: Preclinical and clinical studies. Eur. J. Pharm. Biopharm. 2011, 77, 43-55. [CrossRef]

66. Khoee, S.; Yaghoobian, M. Niosomes: A novel approach in modern drug delivery systems. In Nanostructures for Drug Delivery; Elsevier: Amsterdam, The Netherlands, 2017; pp. 207-237.

67. Eldeeb, E.A.; Salah, S.; Ghorab, M. Proniosomal gel-derived niosomes: An approach to sustain and improve the ocular delivery of brimonidine tartrate; formulation, in-vitro characterization, and in-vivo pharmacodynamic study. Drug Deliv. 2019, 26, 509-521. [CrossRef] [PubMed]

68. Arafa, M.G.; Ayoub, B.M. DOE optimization of nano-based carrier of pregabalin as hydrogel: New therapeutic \& chemometric approaches for controlled drug delivery systems. Sci. Rep. 2017, 7, 41503. [PubMed]

69. Al-mahallawi, A.M.; Khowessah, O.M.; Shoukri, R.A. Nano-transfersomal ciprofloxacin loaded vesicles for non-invasive trans-tympanic ototopical delivery: In-Vitro optimization, ex-vivo permeation studies, and in-vivo assessment. Int. J. Pharm. 2014, 472, 304-314. [CrossRef] [PubMed]

70. John, B. Application of desirability function for optimizing the performance characteristics of carbonitrided bushes. Int. J. Ind. Eng. Comput. 2013, 4, 305-314. [CrossRef]

71. Akhilesh, D.; Faishal, G.; Prabhu, P.; Kamath, J. Development and Optimization of Proniosomes for Oral delivery of Glipizide. Int J. Pharm. Pharm. Sci. 2012, 4, 307-314.

72. Khudair, N.; Agouni, A.; Elrayess, M.A.; Najlah, M.; Younes, H.M.; Elhissi, A. Letrozole-loaded nonionic surfactant vesicles prepared via a slurry-based proniosome technology: Formulation development and characterization. J. Drug Deliv. Sci. Technol. 2020, 58, 101721. [CrossRef]

73. Bhama, S. Development and evaluation of letrozole loaded proniosomes as drug delivery system. Int. J. Res. Pharm. Sci. 2015, 6, 363-368.

74. Alemi, A.; Reza, J.Z.; Haghiralsadat, F.; Jaliani, H.Z.; Karamallah, M.H.; Hosseini, S.A.; Karamallah, S.H. Paclitaxel and curcumin coadministration in novel cationic PEGylated niosomal formulations exhibit enhanced synergistic antitumor efficacy. J. Nanobiotechnology 2018, 16, 28. [CrossRef] [PubMed]

75. Ismail, E.; Sabry, D.; Mahdy, H.; Khalil, M. Synthesis and Characterization of some Ternary Metal Complexes of Curcumin with 1, 10-phenanthroline and their Anticancer Applications. J. Sci. Res. 2014, 6, 509-519. [CrossRef]

76. Ren, W.; Tian, G.; Jian, S.; Gu, Z.; Zhou, L.; Yan, L.; Jin, S.; Yin, W.; Zhao, Y. TWEEN coated NaYF 4: $\mathrm{Yb}, \mathrm{Er} / \mathrm{NaYF} 4$ core/shell upconversion nanoparticles for bioimaging and drug delivery. Rsc. Adv. 2012, 2, 7037-7041. [CrossRef]

77. El-Sayed, M.M.; Hussein, A.K.; Sarhan, H.A.; Mansour, H.F. Flurbiprofen-loaded niosomes-in-gel system improves the ocular bioavailability of flurbiprofen in the aqueous humor. Drug Dev. Ind. Pharm. 2017, 43, 902-910. [CrossRef]

78. Sun, P.; Yang, H.-J.; Wang, Y.-Q.; Liu, K.-Z.; Xu, Y.-W. Lipase-catalyzed synthesis and characterization of stearic acid dextrin ester. Res. Health Nutr. 2013, 1, 7-11.

79. Sadeghi Ghadi, Z.; Ebrahimnejad, P. Curcumin entrapped hyaluronan containing niosomes: Preparation, characterisation and in vitro/in vivo evaluation. J. Microencapsul. 2019, 36, 169-179. [CrossRef]

80. Chopra, M.; Jain, R.; Dewangan, A.K.; Varkey, S.; Mazumder, S. Design of curcumin loaded polymeric nanoparticles-optimization, formulation and characterization. J. Nanosci. Nanotechnol. 2016, 16, 9432-9442. [CrossRef]

81. Fang, J.-Y.; Fang, C.-L.; Liu, C.-H.; Su, Y.-H. Lipid nanoparticles as vehicles for topical psoralen delivery: Solid lipid nanoparticles (SLN) versus nanostructured lipid carriers (NLC). Eur. J. Pharm. Biopharm. 2008, 70, 633-640. [CrossRef] 
82. Pramod, K.; Suneesh, C.V.; Shanavas, S.; Ansari, S.H.; Ali, J. Unveiling the compatibility of eugenol with formulation excipients by systematic drug-excipient compatibility studies. J. Anal. Sci. Technol. 2015, 6, 34. [CrossRef]

83. Rahman, S.A.; Abdelmalak, N.S.; Badawi, A.; Elbayoumy, T.; Sabry, N.; Ramly, A.E. Formulation of tretinoin-loaded topical proniosomes for treatment of acne: In-vitro characterization, skin irritation test and comparative clinical study. Drug deliv. 2015, 22, 731-739. [CrossRef]

84. Das, S. Study of Decomposition Behaviour of Binders and the Effect of Binder Type on Strength and Density of Alumina Samples. Ph.D. Thesis, National Institute of Technology Rourkela, Rourkela, India, May 2011.

85. Patil, H.N.; Hardikar, S.R.; Bhosale, A.V. Formulation development and evaluation of proniosomal gel of carvedilol. Int. J. Pharm. Pharm. Sci. 2012, 4, 191-197.

86. Kazi, K.M.; Mandal, A.S.; Biswas, N.; Guha, A.; Chatterjee, S.; Behera, M.; Kuotsu, K. Niosome: A future of targeted drug delivery systems. J. Adv. Pharm. Technol. Res. 2010, 1, 374. [PubMed]

87. Das, M.K.; Palei, N.N. Sorbitan ester niosomes for topical delivery of rofecoxib. Indian J. Exp. Biol. 2011, 49, 438-445. [PubMed]

88. Caracciolo, G.; Pozzi, D.; Caminiti, R.; Marianecci, C.; Moglioni, S.; Carafa, M.; Amenitsch, H. Effect of hydration on the structure of solid-supported Niosomal membranes investigated by in situ energy dispersive X-ray diffraction. Chem. Phys. Lett. 2008, 462, 307-312. [CrossRef]

89. Junyaprasert, V.B.; Teeranachaideekul, V.; Supaperm, T. Effect of charged and non-ionic membrane additives on physicochemical properties and stability of niosomes. AAPS PharmSciTech 2008, 9, 851. [CrossRef] [PubMed]

90. Essa, E.A. Effect of formulation and processing variables on the particle size of sorbitan monopalmitate niosomes. Asian J. Pharm 2014, 4, 227-233. [CrossRef]

91. Uchechi, O.; Ogbonna, J.D.; Attama, A.A. Nanoparticles for dermal and transdermal drug delivery. Appl. Nanotechnol. Drug Deliv. 2014, 4, 193-227.

92. Al-Hashemi, H.M.B.; Al-Amoudi, O.S.B. A review on the angle of repose of granular materials. Powder Technol. 2018, 330, 397-417. [CrossRef]

93. Agnihotri, S.A.; Soppimath, K.S.; Betageri, G.V. Controlled release application of multilamellar vesicles: A novel drug delivery approach. Drug Deliv. 2010, 17, 92-101. [CrossRef] [PubMed]

94. Zarrouk, K.; Piret, J.; Boivin, G. Herpesvirus DNA polymerases: Structures, functions and inhibitors. Virus Res. 2017, 234, 177-192. [CrossRef] [PubMed]

95. Dallakyan, S.; Olson, A.J. Small-molecule library screening by docking with PyRx. In Chemical Biology; Springer: New York, NY, USA, 2015; pp. 243-250.

96. Hu, L.; Zhang, Y.; Zhu, H.; Liu, J.; Li, H.; Li, X.-N.; Sun, W.; Zeng, J.; Xue, Y.; Zhang, Y. Filicinic Acid Based Meroterpenoids with Anti-Epstein-Barr Virus Activities from Hypericum japonicum. Org. Lett. 2016, 18, 2272-2275. [CrossRef] [PubMed]

97. Sterling, T.; Irwin, J.J. ZINC 15-ligand discovery for everyone. J. Chem. Inf. Modeling 2015, 55, $2324-2337$. [CrossRef] [PubMed]

98. Laskowski, R.A.; Swindells, M.B. LigPlot+: Multiple Ligand-Protein Interaction Diagrams for Drug Discovery; ACS Publications: Washington, DC, USA, 2011.

99. Fukunishi, Y.; Yamasaki, S.; Yasumatsu, I.; Takeuchi, K.; Kurosawa, T.; Nakamura, H. Quantitative Structure-activity Relationship (QSAR) Models for Docking Score Correction. Mol. Inform. 2017, 36, 1600013. [CrossRef] [PubMed]

100. Elgazar, A.A.; Knany, H.R.; Ali, M.S. Insights on the molecular mechanism of anti-inflammatory effect of formula from Islamic traditional medicine: An in-silico study. J. Tradit. Complementary Med. 2019, 9, $353-363$. [CrossRef] [PubMed]

101. Rollinger, J.M.; Stuppner, H.; Langer, T. Virtual screening for the discovery of bioactive natural products. In Natural Compounds as Drugs Volume I; Springer: New York, NY, USA, 2008; pp. 211-249.

102. Kitchen, D.B.; Decornez, H.; Furr, J.R.; Bajorath, J. Docking and scoring in virtual screening for drug discovery: Methods and applications. Nat. Rev. Drug Discov. 2004, 3, 935-949. [CrossRef] [PubMed]

103. Mujoriya, R.Z.; Bodla, R. Niosomes-challenge in preparation for pharmaceutical scientist. Int. J. App. Pharm. 2011, 3, 11-15.

104. Monavari, S.H. The inhibitory effect of Acyclovir loaded nano-niosomes against herpes simplex virus type-1 in cell culture. Med. J. Islamic Repub. Iran 2014, 28, 99. 
105. Shah, J.; Nair, A.B.; Shah, H.; Jacob, S.; Shehata, T.M.; Morsy, M.A. Enhancement in antinociceptive and anti-inflammatory effects of tramadol by transdermal proniosome gel. AJPS 2019. [CrossRef]

106. Aboelwafa, A.A.; El-Setouhy, D.A.; Elmeshad, A.N. Comparative study on the effects of some polyoxyethylene alkyl ether and sorbitan fatty acid ester surfactants on the performance of transdermal carvedilol proniosomal gel using experimental design. AAPS PharmSciTech 2010, 11, 1591-1602. [CrossRef]

107. Feng, J.Y.; Murakami, E.; Zorca, S.M.; Johnson, A.A.; Johnson, K.A.; Schinazi, R.F.; Furman, P.A.; Anderson, K.S. Relationship between antiviral activity and host toxicity: Comparison of the incorporation efficiencies of 2' , 3'-dideoxy-5-fluoro-3'-thiacytidine-triphosphate analogs by human immunodeficiency virus type 1 reverse transcriptase and human mitochondrial DNA polymerase. Antimicrob. Agents Chemother. 2004, 48, 1300-1306.

108. Brezáni, V.; Leláková, V.; Hassan, S.T.; Berchová-Bímová, K.; Nový, P.; Klouček, P.; Maršík, P.; Dall’Acqua, S.; Hošek, J.; Šmejkal, K. Anti-Infectivity against Herpes Simplex Virus and Selected Microbes and Anti-Inflammatory Activities of Compounds Isolated from Eucalyptus globulus Labill. Viruses 2018, 10, 360. [CrossRef] [PubMed]

109. Da Mata, É.C.G.; Mourão, C.B.F.; Rangel, M.; Schwartz, E.F. Antiviral activity of animal venom peptides and related compounds. J. Venom. Anim. Toxins Incl. Trop. Dis. 2017, 23, 3. [CrossRef] [PubMed]

110. Colpitts, C.C.; Schang, L.M.; Rachmawati, H.; Frentzen, A.; Pfaender, S.; Behrendt, P.; Brown, R.J.; Bankwitz, D.; Steinmann, J.; Ott, M. Turmeric curcumin inhibits entry of all hepatitis $\mathrm{C}$ virus genotypes into human liver cells. Gut 2014, 63, 1137-1149.

Sample Availability: Samples of the compounds are not available from the authors.

Publisher's Note: MDPI stays neutral with regard to jurisdictional claims in published maps and institutional affiliations.

(C) 2020 by the authors. Licensee MDPI, Basel, Switzerland. This article is an open access article distributed under the terms and conditions of the Creative Commons Attribution (CC BY) license (http://creativecommons.org/licenses/by/4.0/). 